\title{
Review
}

\section{Strategies to Improve the Efficiency of Somatic Cell Nuclear Transfer}

\author{
Kanokwan Srirattana ${ }^{1}$, Masahiro Kaneda ${ }^{2}$ (D) and Rangsun Parnpai ${ }^{1, * \mathbb{D}}$ \\ 1 Embryo Technology and Stem Cell Research Center, School of Biotechnology, \\ Institute of Agricultural Technology, Suranaree University of Technology, \\ Nakhon Ratchasima 30000, Thailand; kanokwan.sri@sut.ac.th \\ 2 Laboratory of Veterinary Anatomy, Division of Animal Life Science, \\ Tokyo University of Agriculture and Technology, Tokyo 183-8509, Japan; kanedam@cc.tuat.ac.jp \\ * Correspondence: rangsun@g.sut.ac.th; Tel.: +66-442-242-34
}

Citation: Srirattana, K.; Kaneda, M.; Parnpai, R. Strategies to Improve the Efficiency of Somatic Cell Nuclear Transfer. Int. J. Mol. Sci. 2022, 23, 1969. https://doi.org/10.3390/ ijms23041969

Academic Editor: Il-Keun Kong

Received: 28 November 2021

Accepted: 8 February 2022

Published: 10 February 2022

Publisher's Note: MDPI stays neutral with regard to jurisdictional claims in published maps and institutional affiliations.

Copyright: (C) 2022 by the authors. Licensee MDPI, Basel, Switzerland. This article is an open access article distributed under the terms and conditions of the Creative Commons Attribution (CC BY) license (https:// creativecommons.org/licenses/by/ $4.0 /)$.

\begin{abstract}
Mammalian oocytes can reprogram differentiated somatic cells into a totipotent state through somatic cell nuclear transfer (SCNT), which is known as cloning. Although many mammalian species have been successfully cloned, the majority of cloned embryos failed to develop to term, resulting in the overall cloning efficiency being still low. There are many factors contributing to the cloning success. Aberrant epigenetic reprogramming is a major cause for the developmental failure of cloned embryos and abnormalities in the cloned offspring. Numerous research groups attempted multiple strategies to technically improve each step of the SCNT procedure and rescue abnormal epigenetic reprogramming by modulating DNA methylation and histone modifications, overexpression or repression of embryonic-related genes, etc. Here, we review the recent approaches for technical SCNT improvement and ameliorating epigenetic modifications in donor cells, oocytes, and cloned embryos in order to enhance cloning efficiency.
\end{abstract}

Keywords: cloning efficiency; embryo; epigenetic modification; nuclear reprogramming; somatic cell nuclear transfer

\section{Introduction}

Somatic cell nuclear transfer (SCNT) or cloning involves transferring a donor cell into an enucleated oocyte, enabling the reprogramming of terminally differentiated cells into totipotent cells [1]. Since the first cloned sheep, Dolly, was born in 1996 [1], cloned offspring have been successfully produced in 23 mammalian species (reviewed by [2]). SCNT is a unique tool for multiplying genetically valuable animals, wildlife conservation, genetically modified animal production, and biomedical application (reviewed by $[3,4]$ ). However, overall cloning efficiency is still low, varying between 0.1 and $16.0 \%$ (reviewed by $[5,6])$. The low percentage of healthy cloned offspring per transferred embryos is a bottleneck for scientific and commercial applications. A number of abnormalities such as chromosomal aberrations, incompatibility between mitochondrial and nuclear genomes, large offspring syndrome, and placental dysfunction-related disorders have been found in cloned embryos, conceptuses, and offspring [2,7-11], which is believed to be caused by incomplete or unfaithful epigenetic remodeling and reprogramming of donor cell nuclei [12-14]. Many researchers have investigated the effects of donor cell type, oocyte maturation stage, SCNT protocol, embryo activation method, culture condition, etc. on the developmental potential, embryo quality, pregnancy rate, and birth rate of cloned embryos in order to improve cloning efficiency (reviewed by $[15,16])$. Optimizing these cloning parameters could increase cloning efficiency, but it remains low. These strategies might not be enough to make a significant improvement in cloning efficiency (reviewed by [17]). Notably, aberrant epigenetic modifications have been found in cloned embryos, which affect low cloning efficiency, abnormal cloned embryo phenotype, and low viability cloned 
animals (reviewed by $[17,18]$ ). Epigenetic modifications such as DNA methylation, histone acetylation, histone methylation, genomic imprinting, and X-chromosome inactivation are crucial events for the nuclear reprogramming process (reviewed by [15,19]). Theoretically, epigenetic modifications of the donor cell nuclei or cloned embryo could increase accessibility for reprogramming [20].

Epigenetic modifications such as DNA methylation and histone modifications are key factors to regulate gene expression, and they play an important role on embryonic development [21,22]. The developmental efficiency to the blastocyst stage of cloned embryos depends on the donor cell's ability to reprogram its genome to that of a zygote. Differentiated bovine somatic cells and cloned embryos had higher levels of DNA methylation than gametes and early embryos produced in vivo [23]. Methylation at the 5-position of cytosine $(5 \mathrm{mC})$ is an important epigenetic modification during mammalian embryo development as it is involved in regulating gene expression, genomic imprinting, transposon silencing, and $X$ chromosome inactivation (reviewed by [24]). DNA methylation is established and maintained by DNA methyltransferases (DNMTs) and erased by ten-eleven translocation (TET) proteins [25]. Treatment with DNA methyltransferase inhibitors (DNMTi) could reduce the DNA methylation level. Moreover, the histone acetylation level of cloned embryos was significantly lower and different from that of in vitro fertilized (IVF) embryos in cattle, rabbits, and pigs [26-28]. Histone acetylation is regulated by histone acetyltransferase (HAT) and histone deacetylase (HDAC) enzymes. HAT opens up chromatins, which increases the accessibility of transcriptional factors and epigenetic modifiers to DNA. HDAC stimulates gene silencing [29]. Histone deacetylase inhibitors (HDACi) prevent the removing of acetyl groups from lysine residues of histone, resulting in chromatin still opening up, leading to gene expression. Notably, non-specific modulator agents such as DNMTi and HDACi target the entire chromatin landscape, which globally modulated DNA methylation and histone acetylation, respectively.

In this review, we discussed the current knowledge of improving the SCNT procedure, in vitro maturation (IVM), in vitro culture (IVC) media, modification of donor cells, oocytes and cloned embryos, and amelioration of epigenetic status during SCNT in order to increase cloning efficiency.

\section{Technical Improvement of SCNT}

The traditional SCNT method using micromanipulator was used to produce the first cloned sheep, Dolly [1]. Briefly, the meiotic spindle complex of metaphase II (MII) oocyte is enucleated using a specialized micropipette under an inverted microscope equipped with a micromanipulator. Then, a single donor cell is transferred into the perivitelline space of the enucleated oocyte by a micropipette. After electrofusion of the transferred donor cell with an enucleated oocyte, reconstructed oocytes are chemically activated and are cultured in the culture media [1]. The traditional SCNT method is well established and has been employed to produce cloned animals by a large number of research groups (reviewed by [17]). SCNT involves a series of procedures including donor cell preparation, oocyte maturation, enucleation, donor cell injection, fusion, activation, embryo culture, and embryo transfer [1]. Suboptimal conditions of any of these steps can have substantial effects on the development of cloned embryos and offspring.

In large animals such as cattle, buffaloes, and pigs, the meiotic spindle complex of MII oocytes is hardly detectable due to the high lipid content in the cytoplasm. MII spindles are normally identified by fluorescence staining (Hoechst 33342) and visualized under ultraviolet (UV) light [1]. However, exposing with UV light has detrimental effects on embryo development. An alternative method is blind enucleation. The 1st polar body (1st PB) and a small volume of cytoplasm underneath the 1st PB are squeezed out. The squeezed-out cytoplasm is stained with Hoechst 33342 and examined under UV light to identify MII spindles. Therefore, an enucleated oocyte is not exposed to UV light [30]. Later, a non-invasive spindle imaging system, polarized light birefringence has been used to enhance the efficiency of enucleation. However, the imaging system is expensive [31]. On 
the other hand, meiotic spindles of mouse and rat oocytes are easy to identify under phase contrast microscope, and therefore, neither UV light exposure nor expensive equipment is required. Recently, a robotic label-free precise enucleation was established in cloned pigs. This technique reduced the cytoplasmic loss during enucleation by $60 \%$ with an enucleation success rate of $95 \%$. The cloned embryos derived from robotic enucleated oocytes had a two times higher cleavage rate than that of blind enucleated oocytes [32].

There are three procedures to transfer and fuse a donor cell with an enucleated oocyte. Firstly, a single donor cell is inserted into the perivitelline space of an enucleated oocyte, after which the donor cell-cytoplast couplets are fused using electric pulses; this method is known as electrofusion [1]. Later, in 1998, the first cloned mouse was produced by a single-step SCNT, which is also known as the Honolulu technique. The donor cell's nucleus is extracted and is directly injected into an enucleated oocyte using a piezoelectric device [33]. The third technique is a virus-mediated cell fusion using inactivated Sendai virus [34]. This technique was applied as an alternative procedure to induce cell fusion in cloned mice [35].

As described previously, traditional SCNT requires micromanipulation skills and expensive equipment. The handmade cloning (HMC) technique has been established to solve these problems. HMC is a simplified SCNT with no requirement for a micromanipulator [36]. For enucleation, the zona pellucida of the oocyte is removed by enzymatic digestion. Next, the zona-free oocyte is bisected by hand using an ultra-sharp blade under a stereomicroscope. Chromosome-free hemi-cytoplasts are selected by Hoechst 33342 staining. Then, a donor cell is fused with two hemi-cytoplasts to restore the original oocyte volume [37]. HMC has been used to produce cloned animals such as cattle [38,39], horses [40], pigs [41], buffaloes [42], sheep [43], and camels [44]. However, HMC has some disadvantages such as the zona-free embryos might be exposed to toxic substances during IVC, the requirement for a large number of oocytes, as HMC needs two oocytes to make one embryo, and mitochondria heteroplasmy issues. Therefore, a modified handmade cloning ( $\mathrm{mHMC}$ ) technique that does not require the bisection process has been established to solve the oocyte waste during enucleation and mitochondria heteroplasmy. During enucleation, a small volume of cytoplasm containing the chromosome of a zona-free oocyte is removed using a pulled Pasteur pipette under a stereomicroscope $[45,46]$. Therefore, only one oocyte is required to produce a cloned embryo. mHMC has been used to produce cloned blastocysts in sheep [45], pigs [47], and cloned offspring in goats [48], cattle [49], and camels [50]. The use of different SCNT techniques among different cloning laboratories varies due to animal species, equipment availability, and the technical skills of workers.

Slaughterhouse-derived oocytes are typically used for the large-scale production of cloned embryos in many livestock species. The oocytes are normally selected by the morphological appearance. Staining with Brilliant Cresyl Blue (BCB) was first used as a marker to pre-select porcine oocytes [51]. Growing oocytes have high levels of glucose6-phosphate dehydrogenase (G6PDH) activity, which can reduce BCB to a colorless state $(\mathrm{BCB}-)$. At the end of the oocyte growth phase, G6PDH activity is inactive. Therefore, the fully grown oocytes have blue cytoplasm $(\mathrm{BCB}+)$ [52]. BCB staining has been widely used for selecting good quality oocytes in various species, including cattle [53,54], goats [55], horses [56], pigs [57,58], sheep [59,60], buffaloes [61,62], rabbits [63], mice [64], rats [65], dogs [66], cats $[67,68]$, camels [69], and humans [70]. BCB+ oocytes had a higher maturation rate $[56,62,63,69-71]$, mitochondrial DNA (mtDNA) copy number [57,58], blastocyst rate $[53,54,61,63]$, calving rate $[54]$, as well as total cell number $[54,63]$ and inner cell mass (ICM) to trophectoderm (TE) ratio [54,61,63] when compared with those of BCB- oocytes. Furthermore, cloned blastocysts derived from BCB+ oocytes had higher levels of histone H3 lysine 18 acetylation (H3K18ac) [54,61], OCT4, SOX2, and CDX2 expression [54,61], and also had lower apoptosis cells $[54,63]$. Therefore, BCB staining can be used as a reliable method for oocyte selection, thus enhancing cloning efficiency.

Numerous research groups have attempted to determine suitable donor cell types and cell synchronization methods in order to improve cloning efficiency. The epigenetic states of 
donor cells significantly affect the development of cloned embryos. Zhai et al. reported that mesenchymal stem cells (MSCs) from bone marrow had more active epigenetic markers and fewer repressive epigenetic markers than those of fetal fibroblasts. The cleavage and blastocyst rates of cloned porcine embryos derived from MSCs were significantly higher compared with fetal fibroblasts [72]. The effects of donor cells on cloned embryo development have been reviewed by Gouveia et al. [73].

\section{Impact of Cytoplasmic and Mitochondrial Manipulation}

\subsection{Cytoplasmic and Mitochondrial Supplementation in Enucleated Oocytes}

During enucleation, the MII spindle is taken out with a volume of cytoplasm. Cytoplasmic volume plays an important role in the development of cloned embryos. When $50 \%$ of the cytoplasm was removed from enucleated bovine oocytes, the cell numbers in the cloned blastocysts were significantly low [74]. An increase in cytoplasmic volume by fusion or by aggregation had positive effects on embryo development, supporting the establishment of pregnancies and the birth of a viable cloned calf [75]. Hence, cytoplasm supplementation can be used to restore the cytoplasm loss. Cytoplasm injection cloning technology (CICT) is a modification of the traditional SCNT where approximately $30 \%$ of the cytoplasm of a donor oocyte is injected into the perivitelline space of an enucleated oocyte. CICT can increase cytoplasmic volume of an enucleated oocyte without removing the zona pellucida [76]. Additional cytoplasm increased the blastocyst formation rate, embryo quality, and improved epigenetic reprogramming by decreasing expression levels of DNA methylation-related genes (DNMT1 and DNMT3a) of cloned bovine embryos [76]. Similarly, in cloned mice, cytoplasmic supplementation improved the in vitro development and quality of cloned mouse embryos. Additionally, CICT-derived mouse embryos had a lower number of apoptotic cells and higher acetylation levels when compared with those of SCNT-derived embryos [77]. Notably, CICT significantly increased the birth rate of cloned cat embryos when compared to that of SCNT $(4.8 \%$ and $0.7 \%$, respectively) [78]. In contrast, cytoplasm supplementation could not improve cloned porcine embryo development in regard to the blastocyst rate, total cell number, and apoptotic cells. The transcription levels of embryonic lineage differentiation genes (OCT4 and CDX2), pro-apoptotic genes (BAX and $B A K)$, anti-apoptotic gene (BCL2), mitochondria activity-related genes (MFN and TFAM), and methylation-related genes (DNMT1 and DNMT3a) showed no significant differences between cytoplasm supplemented and non-supplemented cloned porcine embryos [79].

Poor-quality and aged oocytes contain low and dysfunctional mitochondria. Mitochondrial supplementation has been shown to positively increase blastocyst rates and the quality of embryos in mice, humans, cattle, and pigs (reviewed by [80]). The combination of mitochondrial supplementation and SCNT (miNT) has been established in a bovine model. Mitochondria was extracted from donor oocytes and then was injected into an enucleated oocyte. Mitochondrial supplementation did not increase the blastocyst formation rate nor the total cell number of cloned bovine embryos. However, miNT-derived blastocysts had a higher mtDNA copy number when compared with that of SCNT. Additional mtDNA led to an increase in the expression of genes involved in the glycolytic metabolism and embryonic development [81]. More studies on mitochondrial supplementation in combination with other assisted reproductive technologies have been recently reviewed by Ferreira et al. [82].

\subsection{Manipulation of Mitochondrial DNA in the Donor Cells Prior to SCNT}

As a whole donor cell is transferred into an enucleated oocyte during SCNT, not only is the nuclear genome passed onto the oocyte but also mitochondria accompanying the donor cell are transferred as well $[83,84]$. There are three possibilities for the fate of mtDNA in cloned embryos: (1) mtDNA is only inherited from the oocyte, while donor cell mtDNA is either not inherited or is eliminated, (2) mtDNA is inherited from the donor cell while oocyte mtDNA is eliminated, and (3) oocyte and donor cell mtDNA coexist. The world's first cloned offspring, Dolly, and the other first set of nine cloned sheep inherited their mtDNA from the oocyte. None of the donor cell mtDNA was found in the 
examined tissues [85]. Oocyte-only mtDNA was also found in cloned bovine embryos and offspring [86]. On the other hand, the co-existence of oocyte and donor cell mtDNA was reported in cloned bovine offspring. The percentage of donor cell mtDNA in the offspring ranged from 0.4 to $4 \%$ [87]. High levels of donor cell mtDNA transmission (40-47\%) have been found in cloned sheep, bovine, and porcine offspring [84,88,89]. In cloned cattle, donor cell mtDNA was found in 54 out of the 60 embryos, three out of the ten fetuses, and three out of the six healthy offspring [90]. Notably, mtDNA from both panda donor cell and rabbit oocyte co-existed at the blastocyst stage of panda-rabbit interspecies SCNT embryos. Panda donor cell mtDNA was detected in fetuses, but the rabbit oocyte mtDNA has been eliminated. However, no live offspring were produced [91]. Previous reports showed that the mtDNA present in somatic cells is likely to have accumulated deletions or mutations as part of the aging process [92,93]. To avoid any confounding outcomes and donor cell mtDNA transmission, mtDNA was depleted from the bovine donor cells by mtDNA depleting agent $\left(2^{\prime}, 3^{\prime}\right.$-dideoxycytidine, ddC). The ddC did not have detrimental effects on chromosomal DNA integrity, as the chromosomes of mtDNA-depleted cells did not exhibit any deletions or duplications when compared with non-depleted cells. Cloned bovine embryos derived from mtDNA-depleted cells harbored only oocyte mtDNA. The mtDNA depletion of the donor cells combined with HDACi (trichostatin A, TSA) treatment of cloned embryos positively modulated the expression levels of genes involved in DNA methylation, embryonic formation, and embryonic development. Taken together, depleting mtDNA from the donor cells prior to SCNT not only prevents the transmission of donor cell mtDNA but also positively modulates the gene expression patterns of cloned bovine embryos [94]. Notably, post-implantation development, calving rate, and the health of the offspring from cloned embryos derived from mtDNA-depleted donor cells need to be determined.

\section{Ameliorate Global DNA Methylation and Histone Acetylation Using DNA Methyltransferase and Histone Deacetylase Inhibitors}

Several strategies have been used to aid epigenetic reprogramming to get normal DNA methylation and chromatin remodeling, which would improve the cloning efficacy as described above. Notably, the first technical breakthrough of HDACi treatment on SCNT was performed by Kishigami et al. in 2006. The cloned mouse embryos were treated with 5-50 nM TSA for $10 \mathrm{~h}$ from the time point of oocyte activation after SCNT [95]. TSA not only increased in vitro embryo development but also enhanced the live birth rate in cloned mice [95-97]. Furthermore, adult ICR mice (an outbred strain), which have never been directly cloned, were successfully produced for the first time when TSA was used [97]. Notably, TSA treatment increased histone acetylation and reduced repressive histone methylation in cloned mouse embryos [98]. These remarkable outcomes gave rise to many researchers to apply TSA with other species. TSA became the most commonly used to improve cloning efficiency in rhesus monkeys [99], pigs [100], rabbits [27], cattle [101], buffaloes [102], and cynomolgus monkeys [103] with optimal concentration and exposure time. The toxicity of TSA can be found at high concentration and long exposure time [104,105]. In recent years, a vast majority of the studies focused on the use of TSA-dependent epigenomic modulation for SCNT in mammals have been carried out to epigenetically modify porcine donor somatic cells [106], donor stem cells [107], activated SCNT-derived oocytes, and resultant embryos [108,109]. Nevertheless, a number of reports showed that TSA had no beneficial effect in cloned cattle [26,110-112], sheep [113], and gaur-bovine interspecies SCNT [114]. TSA had a detrimental impact on cloned rabbit embryos [115]. Controversial results may be due to the species-specific difference, time, and concentration of TSA treatment. Although TSA could broadly correct aberrant acetylation in many regions of cloned embryos, some regions remained hypoacetylated [116,117].

Another HDACi that was less toxic, Scriptaid (6-(1,3-dioxo-1H, 3H-benzo[de]isoquinolin2-yl)-hexanoic acid hydroxyamide), improved cloning efficiency in inbred mice [104], inbred miniature pigs [118], and sheep [119]. Furthermore, Scriptaid was more effective at 
enhancing the in vitro development in cloned mice and sheep than TSA [104,119]. Scriptaid supplementation in IVC media promoted a two-fold increase in the blastocyst rate of cloned canine embryos [120]. Scriptaid also significantly increased the total cell number of cloned porcine embryos at the blastocyst stage [121]. The supplementation of Bufexamac, an HDACi in porcine IVM media, had no significant effect on the maturation rate, but it increased the histone H3 lysine 9 (H3K9), histone H3 lysine 14 (H3K14), and histone $\mathrm{H} 4$ lysine 8 (H4K8) acetylation levels of porcine oocytes. Moreover, Bufexamac treatment significantly increased the blastocyst rate and upregulated the OCT4 and CDX2 expression of cloned porcine embryos [122]. Other HDACi such as sodium butyrate (NaBu) [123], mcarboxycinnamic acid bishydroxamide [124], oxamflatin [125], suberoylanilide hydroxamic acid (SAHA) [125], valproic acid (VPA) [126], psammaplin A [127], abexinostat [128], belinostat [129], dacinostat [130], mocetinostat [131], and quisinostat [132] have been used to enhance the reprogramming ability of the donor cells in cloned embryos and, as a consequence, to improve their developmental competences and molecular quality.

When bovine donor cells were treated with a DNMTi, 5-aza-2'-deoxycytidine (5-aza$\mathrm{dC})$, the global methylation of chromatin in the donor cells was decreased. However, no improvement on the blastocyst rate of cloned bovine embryos was found $[23,133]$. The treatment of donor cells with $S$-adenosylhomocysteine (SAH), another DNMTi, induced global DNA demethylation and increased the blastocyst rate of cloned bovine embryos as well as increased the telomerase activity in both donor cells and cloned embryos [134]. Moreover, the treatment of donor cells with TSA increased the global histone acetylation levels and increased the blastocyst rate of cloned bovine embryos [133,135-137]. NaBu also improved the in vitro development in cloned cattle [135] and rabbits [138]. In contrast, Das et al. found that treatment of cloned porcine embryos with $\mathrm{NaBu}$ increased the blastocyst rate; however, no beneficial effect was found when donor cells were treated with $\mathrm{NaBu}$ [123]. Fang et al. showed that co-treatment of DNMTi (Zebularine) and HDACi (Scriptaid) in ovine donor cells and cloned embryos increased the blastocyst rate and ameliorated the abnormal expression of embryonic development-related genes (OCT4, SOX2, H19, IGF2, and DNMT1) [139]. Although the treatment of donor cells with DNMTi and/or HDACi could increase the blastocyst rates in several species, no or a minor beneficial effect on the birth have been reported. These results suggested that DNMTi and/or HDACi treatment should be performed with embryos, not on the donor cells.

The HDACi- and/or DNMTi-based strategies of epigenomic modulation have been comprehensively reviewed by Samiec and Skrzyszowska [140]. Recently, mouse cloning efficiency could be improved by chlamydocin analogues, which are a family of newly designed agents that specifically inhibit Class I and IIa HDACs. The results showed that one of the chlamydocin analogues, $\mathrm{Ky}-9$, strongly promoted the development of cloned mouse embryos to a level similar to that of TSA [141].

\section{The Use of Non-Chemical and Biological Agents as Epigenetic Modifiers}

While chemical agents have been used to improve cloning efficiency, there are some concerns about the safety of these drugs on the health of offspring. Biological agents or nonchemical treatment are alternatives to overcome this issue. Previous reports showed that cytoplasmic extracts from GV stage oocytes improved the cloning efficiency in sheep [142] and also modified histone methylation, histone acetylation, and embryonic developmentassociated genes (OCT4 and NANOG) in cloned pigs [143].

Vitamin C (L-ascorbic acid), a well-known antioxidant, also acts as an epigenetic modifier. Vitamin $C$ enhanced the activity of the TET protein and promoted the oxidation of $5 \mathrm{mC}$ to 5-hydroxymethylcytosine (5hmC) [144]. The treatment of donor cells with vitamin $\mathrm{C}$ improved the development of cloned bovine embryos [145]. Vitamin C supplementation to IVC media increased the expression levels of transcription factors (OCT4, SOX2, and KLF4) and the acetylation level of histone $\mathrm{H} 4$ lysine 5 (H4K5) as well as increased the full-term development of cloned porcine embryos [146]. Chawalit et al. found that vitamin $\mathrm{C}$ increased the blastocyst rate but did not change H3K9 and H3K14 acetylation levels in 
HMC porcine embryos [147]. In cloned mice, vitamin C significantly increased blastocyst and birth rates. However, no significant effects on the expression of Oct4 and Nanog, H3K14 acetylation, and $\mathrm{H} 3 \mathrm{~K} 9$ methylation (H3K9me) was found [148]. In cloned sheep, the preimplantation development of embryos and the $5 \mathrm{hmC}$ levels in blastocysts were significantly increased when cloned embryos were directly treated with vitamin C. On the other hand, no positive effects were found when the donor cells were treated with vitamin C [149]. This beneficial role of vitamin $C$ on cloned embryos may be attributed to its antioxidant activity and epigenetic modifying function. A combinational treatment of TSA from 0 to $8 \mathrm{~h}$ after activation and vitamin $\mathrm{C}$ from 8 to $15 \mathrm{~h}$ after activation improved the efficiency of mouse cloning from 0 to $15 \%$ and decreased the abnormally high levels of $\mathrm{H} 3 \mathrm{~K} 9$ trimethylation (H3K9me3) and global DNA methylation in cloned mouse embryos [150]. Notably, the birth rate of cloned mouse embryos treated with a combination of vitamin $C$ and psammaplin $A$ was similar to that of vitamin $C$ or psammaplin A alone. Both vitamin $C$ and psammaplin A improved mice cloning efficiency possibly through different mechanisms, as they do not show an additive effect when combined [148].

The supplementation of bovine IVM media with melatonin (a free radical scavenger) decreased the apoptosis level, recovered the integrity of mitochondria, ameliorated the spindle assembly and chromosome alignment, increased the global H3K9 acetylation levels, reduced the $\mathrm{H} 3 \mathrm{~K} 9$ me levels in bovine oocytes, and enhanced the subsequent development of cloned bovine embryos [151]. In cloned cattle, sperm-borne small RNAs regulate $\alpha$ tubulin acetylation and epigenetic modification in cloned embryos. Sperm-borne small RNA injection of cloned bovine embryos enhanced the developmental competence and significantly increased the live birth rate and decreased the birth weights of offspring [152]. Similarly, the injection of sperm small RNA into cloned rabbit embryos increased the total cell number and $\mathrm{H} 3 \mathrm{~K} 9 \mathrm{me} 3$ level as well as decreased the apoptosis index of cloned rabbit blastocysts [153].

\section{Impact of Histone Methylation}

Histone methylation is regulated by histone methyltransferases and histone demethylases, which play important roles at all development stages [154]. H3K9me3, a histone marker of transcriptional repression, is considered a key barrier of cloned embryo development. Using RNA sequencing, the arrested cloned mouse embryos at the two-cell stage cause abnormal gene expression due to the maintenance of $\mathrm{H} 3 \mathrm{~K} 9 \mathrm{me}$ levels [155]. Aberrant epigenetic reprogramming of H3K9me3 was found in cloned cattle [156,157], mice [158], and rabbits [159], which is a major cause of the developmental failure of cloned embryos $[116,160]$. Matoba et al. found that there are the regions enriched for H3K9me3 in cloned mouse embryos at the two-cell stage, unlike in IVF embryos, and they named these regions Reprogramming Resistant Regions (RRRs). Notably, the demethylation of H3K9me3 using H3K9me3-specific demethylase $K d m 4 d$ could reactivate the majority of RRRs and improve cloned mouse efficiency [116]. In cloned sheep, when donor cells were treated with recombinant human KDM4D protein, the levels of $\mathrm{H} 3 \mathrm{~K} 9 \mathrm{me} 3$ and $\mathrm{H} 3 \mathrm{~K} 9$ dimethylation (H3K9me2) were both significantly decreased. KDM4D treatment improved the blastocyst rate, blastocyst quality, and expression of developmental genes including SOX2, NANOG, and CDX2 in cloned sheep [161]. The reduction of H3K9me in donor cells has been reported to enhance the developmental potential in cloned mice [155,162], sheep [161], and pigs [163].

The injection of $\mathrm{H} 3 \mathrm{~K} 9 \mathrm{me} 3$-specific demethylase $\mathrm{Kdm} 4 a$ mRNA reduced $\mathrm{H} 3 \mathrm{~K} 9 \mathrm{me} 3$ activity and increased blastocyst rates, resulting in improving the efficiency of nuclear transfer-derived embryonic stem cell (ntESC) production in humans [160] and live offspring in monkeys [103]. Similarly, the injection of KDM4A mRNA into cloned porcine embryos effectively decreased the $\mathrm{H} 3 \mathrm{~K} 9 \mathrm{me} 3$ level and increased the blastocyst rate; however, the addition of KDM4A significantly elevated the expression levels of XIST (X inactivate specific transcript) in both pre- and post-implantation stage embryos, which may cause post-implantation death in cloned pigs [164]. 
The overexpression of murine $K d m 4 b$ (lysine demethylase $4 \mathrm{~B}$ ) in the bovine donor cells reduced $\mathrm{H} 3 \mathrm{~K} 9 \mathrm{me} 3$ and histone $\mathrm{H} 3$ lysine 36 trimethylation (H3K36me3) levels, and it improved the blastocyst formation rate, but it did not increase post-implantation development in cloned bovine embryos [165]. Furthermore, KDM4B overexpression in cloned bovine embryos reduced the transcriptional level of H3K4me3 and increased 5mC levels [166]. Liu et al. found that $K d m 4 b$ and a histone H3 lysis 4 trimethylation (H3K4me3)-specific demethylase $(K d m 5 b)$ were identified as the key factors for two-cell and four-cell arrest of cloned mouse embryos, respectively. The co-injection of $K d m 4 b$ and $K d m 5 b$ mRNAs during SCNT could restore transcriptional profiles by reducing the abnormal methylation levels in cloned embryos and increased blastocyst development as well as the pregnancy and birth rates of cloned mice [155]. Two H3K9-specific demethylase genes, KDM4D and KDM4E, are related to the active demethylation of $\mathrm{H} 3 \mathrm{~K} 9 \mathrm{me} 3$ and $\mathrm{H} 3 \mathrm{~K} 9 \mathrm{me} 2 . \mathrm{KDM} 4 \mathrm{D}$ and $\mathrm{KDM} 4 \mathrm{E}$ were deficiently expressed in cloned bovine embryos at the eight-cell stage. The overexpression of $K D M 4 E$ can restore the global transcriptome, improve blastocyst formation, and increase the efficiency of bovine cloning. Hence, KDM4E is also essential for H3K9 demethylation during embryonic genome activation [162].

Previous reports showed that specific histone methyltransferases inhibitors can be used to modulate H3K9 methylation. BIX-01294, a specific inhibitor of G9A (histonelysine methyltransferase of H3K9), significantly decreased the levels of H3K9me2 and $\mathrm{H} 3 \mathrm{~K} 9 \mathrm{me}$ in cloned porcine embryos at two-cell and four-cell stages, respectively. BIX-01294 also increased transcriptional expression of the pluripotency genes (SOX2, NANOG, and OCT4) in cloned porcine embryos at the blastocyst stage. Therefore, BIX-01294 enhanced the developmental competence of cloned porcine embryos through improvements in epigenetic reprogramming and gene expression [167]. On the other hand, BIX-01294 treatment of cloned mouse embryos has beneficial effects in terms of correcting abnormal epigenetic modifications but not on in vitro development [168]. The expression levels of SUV39H1, SUV39H2, DNMT1, DNMT3A, and DNMT3B were abnormally high in cloned porcine embryos when compared with IVF embryos. The treatment of cloned porcine embryos with chaetocin, an H3K9me3-specific methyltransferase inhibitor, significantly increased the embryo developmental rate and expression of pluripotency-related genes [169]. Chaetocin also enhanced epigenetic reprogramming by reducing the $\mathrm{H} 3 \mathrm{~K} 9 \mathrm{me} 3$ and $5 \mathrm{mC}$ levels and restoring the abnormal expression of $\mathrm{H} 3 \mathrm{~K} 9 \mathrm{me} 3$-specific methyltransferases and DNA methyltransferases [170].

Histone H3 lysine 27 trimethylation (H3K27me3) is another repressive epigenetic mark, which is regulated by enhancer of zeste homolog 2 (EZH2) lysine methyltransferases and lysine demethylase $6 \mathrm{~A}$ and $6 \mathrm{~B}(K D M 6 \mathrm{~A} / 6 \mathrm{~B})$. The overexpression of $K d m 6 a$ improves the efficiency of mouse cloning, while $K d m 6 b$ did not. However, the knockdown of $K d m 6 b$ impeded ectopic Xist expression and increased mouse cloning efficiency [171]. The treatment of donor cells and cloned embryos with GSK126 (EZH2 inhibitor) reduced the H3K27me3 levels and enhanced both porcine cloning and iPSCs efficiency. On the other hand, GSK-J4 (KDM6A/6B inhibitor) increased the H3K27me3 level but decreased the development of cloned porcine embryos [172]. Deletions of H3K27me3-imprinted genes (Sfmbt2, Jade1, Gab1, and Smoc1) in donor cells normalized gene expression patterns and also increased cloned mouse efficiency to $14 \%$. Notably, Sfmbt2 deletion was the most effective for improving mouse cloning efficiency [173]. Small interfering RNA (siRNA) has been used to knock down H3K9 methyltransferases, Suv39h1 and Suv39h2, in murine donor cells. The knockdown of Suv39h1/h2 in the donor cells increased the blastocyst formation rate of cloned mouse embryos [116]. Similarly, the knockdown of SUV39H1/H2 in bovine donor cells decreased $\mathrm{H} 3 \mathrm{~K} 9 \mathrm{me} 3$, increased $\mathrm{H} 3 \mathrm{~K} 9$ acetylation (H3K9ac), and repressed DNA methyltransferase gene expression. The knockdown of SUV39H1/H2 also improved cloned bovine embryo development, and these cloned embryos had a similar pattern of gene expression to the IVF embryos [174]. Although the modification of donor cells prior to SCNT could increase the blastocyst rates in several species, only a few beneficial effects on birth have been reported. 


\section{Impact of DNA Methylation and Chromatin Structure}

Ectopic DNMT1 expression has been believed to cause aberrant methylation in cloned bovine embryos [175]. Previous reports showed that donor cell DNMT1 expression can inhibit by DNMTi (5-aza-dC [176,177] and RG108 [178]) and gene knockdown [179]. The knockdown of DNA methyltransferases (Dnmt3a and Dnmt3b) combined with the overexpression of histone demethylases $(K d m 4 b$ and $K d m 5 b)$ reduced the global hyper-methylation status and improved the full-term development of cloned mouse embryos [180].

MicroRNAs are short non-coding regulatory RNA molecules that inhibit translation or contribute to mRNA degradation via binding to the $3^{\prime}$ UTR of target mRNAs [181]. MicroRNA 148a (miR-148a) overexpression in porcine donor cells prior to SCNT significantly decreased the levels of DNMT1 expression and global DNA methylation of the donor cells, and it also significantly increased the blastocyst rate, total cell number, and expression levels of OCT4 and NANOG in cloned porcine embryos [182].

Methyl-CpG-binding domain proteins (MBPs) associate with DNA methylation and histone modification, which are the critical changes of somatic cell reprogramming. MethylCpG-binding protein 2 (Mecp2) expression was significantly low in cloned mouse embryos [183]. The overexpression of Mecp 2 in mouse donor cells increased the blastocyst rate, expression levels of Oct4 and Nanog, and also the $5 \mathrm{hmC}$ level, while it decreased the $5 \mathrm{mC}$ level. Mecp 2 may promote the activity of ten-eleven translocation 3 (Tet3), which mediates active DNA demethylation during mouse pre-implantation embryonic development [183]. Moreover, the overexpression of TET3 in the donor cells increased blastocyst formation rates and embryo quality in cloned goats [184] and cattle [163]. Additionally, methyl-CpGbinding domain protein 3 (MBD3) is a core component of the nucleosome remodeling and deacetylase $(\mathrm{NuRD})$ complex, which is crucial for pluripotent stem cell differentiation and embryonic development. The overexpression of $M B D 3$ in cloned porcine embryos increased the blastocyst rate, total cell number, mRNA expression levels, and also decreased the DNA methylation levels of pluripotency genes (OCT4 and NANOG) [185].

In eukaryotes, chromatin is packaged in a hierarchical structure which is associated with many biological processes. Proper higher-order chromatin folding is crucial for gene regulation and chromosome division during mitosis or meiosis (reviewed by [186,187]). The three-dimensional (3D) chromatin structure consists of chromosome territories, chromatin compartments (A/B), Topologically-Associated Domains (TADs), and loops [188]. Proper $3 \mathrm{D}$ chromatin structure establishment is an important step during cell fate transition. The aberrant TADs and compartment A/B organization can be found in cloned mouse embryos that was partially caused by $\mathrm{H} 3 \mathrm{~K} 9 \mathrm{me} 3$ in the donor cells. The injection of $K d m 4 d$ mRNA could partially rescue un-disassembled H3K9me3-marked TADs in cloned mouse embryos at the two-cell stage [189]. Cohesion is an essential protein complex for loop and TAD formation [190-192]. Zhang et al. found that removing cohesion from donor cells prior to SCNT rescued the activation of zygotic genome activation (ZGA) and increased blastocyst rate in cloned mice [193].

The abnormal methylation of imprinted genes is commonly observed in cloned embryos, and it is one of the primary reasons for their abnormal development and high mortality. Primordial germ cell 7 (PGC7) maintains the methylation level of imprinted genes by reducing the levels of $5 \mathrm{hmC}$ and increasing levels of $5 \mathrm{mC}$ during embryonic development. $P G C 7$ overexpression in donor cells corrected the aberrant methylation patterns of the imprinted genes (IGF2R, insulin-like growth factor 2 receptor and XIST), reduced the developmental abnormalities in cloned goat embryos, and significantly enhanced both pregnancy and birth rates [194]. Loss of H3K27me3 imprinting causes placental enlargement and a low birth rate of cloned mouse embryos. Correcting the expression of clustered microRNAs within the Sfmbt2 gene ameliorated the placental phenotype; moreover, the birth rates were increased about two-fold [195]. Complete loss of H3K27me3 imprinting was found in cloned mouse embryos, which caused the postnatal developmental defects [196]. No significant differential expression of H3K27me3-imprinted genes was found in cloned porcine or cloned bovine embryos. This indicated that the H3K27me3-imprinting system 
may not be conserved in large-animal species [197]. In fact, the loss of imprinting in Sfmbt2 of cloned mouse embryos contributed to placental overgrowth. However, SFMBT2 is not an imprinted gene in pig, cattle, and human [198].

\section{Impact of $X$ Inactivates Specific Transcript Modification}

$\mathrm{X}$ chromosome inactivation $(\mathrm{XCI})$ is a process in which one of the two $\mathrm{X}$ chromosomes in female cells are inactivated during early embryonic development. A long non-coding RNA gene, XIST, is responsible for XCI [199]. The ectopic expression of XIST, which is one of the major epigenetic errors, has been found in both male and female cloned mice [200], cattle [200,201], and pigs [164]. The abnormal expression of XIST may be associated with high neonatal mortality in cloned animals [202]. XIST knockout in male porcine donor cells modulated aberrant XIST expression and reduced global H3K9me3 in cloned porcine embryos [164]. The knockdown of Xist combined with TSA treatment in cloned mouse embryos could improve the birth rate and cloning efficiency [203]; however, the knockdown of Xist only works in males [204]. Notably, the knockout of Xist on active X chromosome in cloned mouse embryos showed normal global gene expression and resulted in an eightto nine-fold increase in cloning efficiency in both male and female [200]. Nevertheless, the injection of anti-XIST siRNA into male cloned porcine embryos slightly increased embryonic development [205]. Later, Yang et al. reported that the injection of anti-XIST short hairpin RNA (shRNA) into cloned porcine embryos at the two-cell stage reduced XIST expression and enhanced the developmental ability of cloned embryos derived from male donor cells [206]. Notably, a combination of Xist knockout in donor cells and overexpression of $K d m 4 d$ could increase by more than $20 \%$ efficiency of mouse cloning [196].

\section{Alternative Methods for Cloning Efficiency Improvement}

Many studies using other chemical and non-chemical strategies to improve cloning efficiency have been reported as described below.

Granulocyte colony-stimulating factor (G-CSF), a pleiotropic cytokine, belongs to the hematopoietic growth factor family. The level of G-CSF in the follicular fluid is a predictive biomarker of oocyte and embryo developmental competence after IVF and intracytoplasmic sperm injection (ICSI) in humans [207]. The supplementation of human recombinant G-CSF in porcine IVC media significantly enhanced blastocyst rate and the total cell number, and it significantly decreased apoptotic cells in cloned porcine blastocysts. Moreover, the transcriptional levels of anti-apoptosis (BCL2)-, proliferation (PCNA)-, and pluripotency (POU5F1)-related genes were dramatically upregulated [208]. In bovine cloning, follistatin supplementation during the first $72 \mathrm{~h}$ of IVC significantly increased both blastocyst rate and CDX2 expression in cloned blastocysts [209]. In addition, adiponectin (a protein hormone and adipokine) supplementation in IVC media significantly increased cleavage and blastocyst rates as well as the total cell number of cloned porcine embryos. Adiponectin reduced the level of XBP1 expression and ER stress-related genes, enhanced the expression levels of NANOG and SOX2, and decreased that of Caspase-3 [210].

Resveratrol (a natural plant-derived antitoxin) treatment of porcine oocytes during IVM increased the maturation rate, blastocyst rate, and the blastocyst cell number in cloned porcine embryos. Resveratrol improved the quality of porcine oocytes by protecting them from oxidative damage and apoptosis [211]. Rhodiola sachalinensis is an herb commonly used in traditional Chinese medicine. The supplementation of $R$. sachalinensis aqueous extract (RSAE) to porcine IVM media did not improve the maturation rate, but it significantly increased the intracellular glutathione level in porcine oocytes. Moreover, RSAE enhanced the cleavage and blastocyst rates of cloned porcine embryos [212]. Asiatic acid is a pentacyclic triterpene enriched in the medicinal herb Centella asiatica, and it has been suggested to possess free radical scavenging and anti-apoptotic properties. Asiatic acid supplementation during the IVC improved developmental competence and embryo quality in cloned porcine embryos. Asiatic acid not only enhanced intracellular GSH levels but also attenuated mitochondrial dysfunction. Asiatic acid upregulated expression of the antioxi- 
dant (SOD1)- and the blastocyst formation (COX2)-related genes while downregulating expression of the apoptosis (CASPASE9)-related gene in cloned porcine blastocysts [213]. Plant-derived nanoparticles are biologically safe and applicable for improving the quality of oocytes and subsequent embryo development. The supplementation of porcine IVM media with modified Spirulina maxima pectin nanoparticles (MSmPNPs) improved the oocyte maturation rate, resulted in a higher cleavage rate, blastocyst development, total cell number, and ratio of ICM:TE compared to the untreated group. MSmPNP treatment increased the level of intracellular glutathione (GSH) while reducing the reactive oxygen species (ROS) level, as well as increasing the expression of the pluripotency-associated genes (POU5F1, DPPA2, and NDP52) in cloned porcine blastocysts [214]. As one of the most powerful natural antioxidants, astaxanthin (Ax) has begun to be applied to the field of reproductive biology. Ax treatment was reported to increase the maturation rate of porcine [215] and bovine oocytes [216]. In contrast, the supplementation of Ax in porcine IVM media did not improve the oocyte maturation rate but significantly increased the cleavage and blastocyst rates of cloned porcine embryos. Moreover, Ax enhanced GDF9 and POU5F1 expression in cloned porcine embryos [217].

Notably, Reversine (2-(4-morpholinoanilino)-6-cyclohexylamino-purine analogue) is a dedifferentiating agent and was shown to induce cell plasticity and promote the reprogramming of several differentiated cells to multipotent progenitor cells [218-221]. Additionally, Reversine modulated the acetylation of histone by changing MEK-dependent signaling, which could alter the reprogramming events in cloned embryos [219]. Reversine treatment increased the blastocyst rate of cloned miniature pig embryos, and normal fetuses were obtained after transferring Reversine-treated embryos into recipients. However, no offspring were born [222].

Sodium chloride is one of the main components regulating the osmolality of a culture medium. The changes in the osmolality affect the maturation of oocytes and embryonic development $[223,224]$. Recently, Lee et al. studied the effects of $\mathrm{NaCl}$ concentration in porcine IVM media. The osmotic pressures of IVM media containing 61.6 (low concentration) and $108 \mathrm{mM}$ (normal concentration) $\mathrm{NaCl}$ were approximately 220 and $285 \mathrm{mOsm}$, respectively. A low concentration of $\mathrm{NaCl}$ did not improve the maturation rate of porcine oocytes but significantly increased the blastocyst rate of cloned porcine embryos when compared with that of oocytes cultured in normal $\mathrm{NaCl}$ concentration [225]. Recently, pulsed electromagnetic fields (PEMF) treatment of cloned buffalo embryos at the beginning of IVC increased the blastocyst rate, decreased the level of apoptosis, and altered the expression levels of pluripotency-, apoptosis-, metabolism-, and stress-related genes [226].

In bovine cloning, the removal of folate (folic acid) from the donor cell culture media decreased the DNA methylation level of the donor cells as well as increased the blastocyst rate of cloned bovine embryos [227]. Alanine (an amino acid that is used in the biosynthesis of proteins) supplementation in porcine IVM media significantly increased cleavage and blastocyst rates after SCNT. Cloned porcine embryos derived from alanine-treated oocytes significantly increased the mRNA expression of POU5F1 and FGFR2, which are associated with oocyte quality and embryonic development [228]. A previous report showed that treatment of aged porcine oocytes with caffeine, a phosphatase inhibitor, can increase the maturation promoting factor (MPF) activity resulting in reducing of spontaneous activation and fragmentation [229]. In cloned sheep, caffeine treatment of oocytes during IVM increased the total cell number of cloned blastocysts [230]. The supplementation of caffeine during oocyte enucleation or post-fusion enhanced the blastocyst rate of cloned porcine embryos by the upregulated expression of POU5F1, SOX2, and NANOG [231]. Manganese supplementation in porcine IVM media significantly increased the blastocyst rate of cloned porcine embryos. However, there was no substantial difference in the cleavage rate and total cell numbers in blastocysts compared to the untreated group. Manganese improved the developmental competence of cloned porcine embryos by increasing GSH and decreasing ROS levels [232]. 
A canonical WNT (wingless-related mouse mammary tumor viruses) signaling pathway has been reported to inhibit embryonic development [233]. Dickkopf-1 (DKK1) is a secretory inhibitor of the canonical WNT signaling pathway. DKK1 supplementation in the IVC media on day 5 of embryo culture could increase blastocyst formation, conception, and birth rates of HMC river buffalo embryos [234]. Genetic instability, including DNA double-strand breaks (DSBs) and chromosome segregation errors, has been found in both cloned human and cloned mouse embryos, resulting in delayed DNA replication and abnormal mitosis [235]. Rad51 homologous 1 (RAD51) is a DNA-binding protein that maintains genome stability and regulates signaling proteins to control the DNA damage response, replication, repair, and recombination (reviewed by [236]). The activity of RAD51 and DSBs were lower in cloned mouse embryos than IVF embryos, which caused a decrease in DNA repair and an increase in genetic instability, resulting in the developmental arrest of cloned embryos [237]. To repair genetic instability or DSBs, cloned mouse embryos were treated with RAD 51-stimulatory compound 1 (RS-1), which is an activator of Rad51. RS-1 treatment recovered RAD51 activity, overcame developmental arrest at the two-cell stage, and also increased blastocyst formation and offspring rates in cloned mouse embryos [237]. A combination of $K d m 4 a$ mRNA injection and RS-1 treatment significantly increased the blastocyst rates of cloned mouse embryos (82.5\%) when compared to those of only Kdm4a injection (66.0\%), only RS-1 treatment (65.9\%), and control cloned embryos (35.1\%) [237].

ZGA is an important process for donor cell reprogramming in cloned embryos. The transcription factor of double homeobox (Dux) was identified as a key inducer of ZGA in normal fertilized embryos [238-240]. The transient overexpression of Dux improved the cloning efficiency in mice and facilitated fully chemically-induced somatic reprogramming. These cloned embryos also had transcriptome profiling similar to that of IVF embryos. Furthermore, the combination of Dux overexpression and Dnmt3a/3b knockdown increased the birth rate of cloned mice [241]. The overexpression of Dux significantly improved cloned mouse embryo development by correcting the aberrant H3K9ac to overcome twocell arrest [117]. In addition, the overexpression of full-length Dux mRNA in cloned mouse embryos improved the efficiency of pre-implantation development and increased the expression of ZGA- related genes (Zscan4 and Mervl) [242].

\section{Concluding Remarks}

We reviewed methods to improve SCNT efficiency by technical optimizations on the SCNT procedure to overcome aberrant epigenetic modifications using chemical and non-chemical treatments, and also targeted modification. Many approaches to assist the nuclear reprogramming have been employed either in donor cells, oocytes, and/or cloned embryos, as summarized in Figure 1. However, significant successes in live birth rates have been mainly reported in mice, while only a few were reported in pigs, cattle, cynomolgus monkeys, and goats (Table 1). Future studies in large animal models are needed. A better understanding on the epigenetic reprogramming is essential to improve overall cloning efficiency. It would also help to develop new approaches to produce cloned animals. 
Table 1. Summary of cloned offspring produced by using epigenetic modulations.

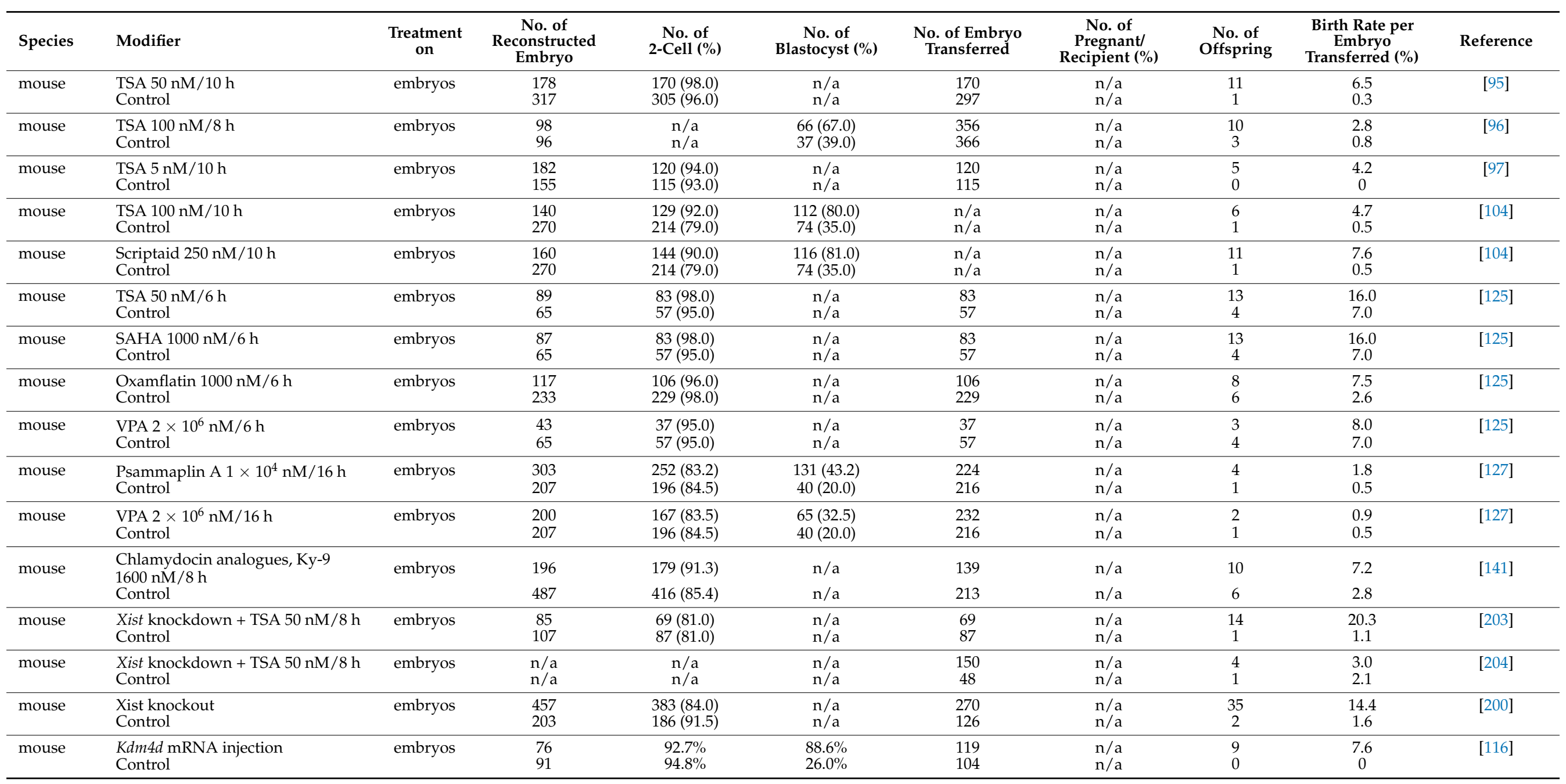


Table 1. Cont.

\begin{tabular}{|c|c|c|c|c|c|c|c|c|c|c|}
\hline Species & Modifier & $\begin{array}{l}\text { Treatment } \\
\text { on }\end{array}$ & $\begin{array}{c}\text { No. of } \\
\text { Reconstructed } \\
\text { Embryo }\end{array}$ & $\begin{array}{c}\text { No. of } \\
\text { 2-Cell (\%) }\end{array}$ & $\begin{array}{c}\text { No. of } \\
\text { Blastocyst (\%) }\end{array}$ & $\begin{array}{l}\text { No. of Embryo } \\
\text { Transferred }\end{array}$ & $\begin{array}{c}\text { No. of } \\
\text { Pregnant/ } \\
\text { Recipient (\%) }\end{array}$ & $\begin{array}{l}\text { No. of } \\
\text { Offspring }\end{array}$ & $\begin{array}{c}\text { Birth Rate per } \\
\text { Embryo } \\
\text { Transferred (\%) }\end{array}$ & Reference \\
\hline mouse & $\begin{array}{l}\text { Xist knockout }+K d m 4 d \\
\text { mRNA injection }\end{array}$ & $\begin{array}{c}\text { donor } \\
\text { cells }+ \\
\text { embryos }\end{array}$ & $\mathrm{n} / \mathrm{a}$ & $\mathrm{n} / \mathrm{a}$ & $\mathrm{n} / \mathrm{a}$ & 85 & $\mathrm{n} / \mathrm{a}$ & 20 & 23.5 & [196] \\
\hline mouse & $\begin{array}{l}K d m 4 b+K d m 5 b \text { mRNA injection } \\
\text { Control }\end{array}$ & oocytes & $\begin{array}{l}\mathrm{n} / \mathrm{a} \\
\mathrm{n} / \mathrm{a}\end{array}$ & $\begin{array}{l}\mathrm{n} / \mathrm{a} \\
\mathrm{n} / \mathrm{a}\end{array}$ & $\begin{array}{l}95.0 \% \\
31.0 \%\end{array}$ & $\begin{array}{l}\mathrm{n} / \mathrm{a} \\
\mathrm{n} / \mathrm{a}\end{array}$ & $\begin{array}{l}\mathrm{n} / \mathrm{a} \\
\mathrm{n} / \mathrm{a}\end{array}$ & $\begin{array}{l}\mathrm{n} / \mathrm{a} \\
\mathrm{n} / \mathrm{a}\end{array}$ & $\begin{array}{c}11.1 \\
1.8\end{array}$ & [155] \\
\hline \multirow[t]{2}{*}{ mouse } & $\begin{array}{l}\text { Dnmt3a/3b siRNA and } K d m 4 b / 5 b \\
\text { mRNA injection }\end{array}$ & \multirow[t]{2}{*}{$\begin{array}{l}\text { donor } \\
\text { cells + } \\
\text { embryos }\end{array}$} & 119 & $\mathrm{n} / \mathrm{a}$ & $92.6 \%$ & 63 & $\mathrm{n} / \mathrm{a}$ & 11 & 17.5 & \multirow[t]{2}{*}{ [180] } \\
\hline & Control & & 121 & $\mathrm{n} / \mathrm{a}$ & $39.5 \%$ & 247 & $\mathrm{n} / \mathrm{a}$ & 2 & 0.8 & \\
\hline mouse & $\begin{array}{l}\text { Kdm6b mRNA injection } \\
\text { Control }\end{array}$ & embryos & $\begin{array}{l}286 \\
176\end{array}$ & $\begin{array}{l}89.1 \% \\
90.9 \%\end{array}$ & $\begin{array}{l}70.8 \% \\
25.5 \%\end{array}$ & $\begin{array}{l}265 \\
120\end{array}$ & $\begin{array}{l}\mathrm{n} / \mathrm{a} \\
\mathrm{n} / \mathrm{a}\end{array}$ & $\begin{array}{c}16 \\
0\end{array}$ & $\begin{array}{c}6.0 \\
0\end{array}$ & [171] \\
\hline \multirow[t]{2}{*}{ mouse } & Sfmbt2 miRNA knockout & \multirow{2}{*}{$\begin{array}{l}\text { donor } \\
\text { cells }\end{array}$} & 102 & $88(86.3)$ & $\mathrm{n} / \mathrm{a}$ & 75 & $\mathrm{n} / \mathrm{a}$ & 5 & 6.7 & \multirow[t]{2}{*}{ [195] } \\
\hline & Control & & 167 & $152(91.0)$ & $\mathrm{n} / \mathrm{a}$ & 101 & $\mathrm{n} / \mathrm{a}$ & 3 & 3.0 & \\
\hline \multirow[t]{2}{*}{ mouse } & $\begin{array}{l}\text { Monoallelic deletion of Sfmbt2, } \\
\text { Jade1,Gab1,Smoc1 }\end{array}$ & \multirow{2}{*}{$\begin{array}{l}\text { donor } \\
\text { cells }\end{array}$} & 135 & $121(89.6)$ & $28(23.0)$ & 49 & $\mathrm{n} / \mathrm{a}$ & 7 & 14.3 & \multirow[t]{2}{*}{ [173] } \\
\hline & Control & & 162 & $141(87.0)$ & $32(21.7)$ & 404 & $\mathrm{n} / \mathrm{a}$ & 0 & 0 & \\
\hline mouse & $\begin{array}{l}\text { RAD51-stimulatory compound } 1 \text { : } \\
1 \times 10^{4} \mathrm{nM} / 22 \mathrm{~h}\end{array}$ & embryos & 169 & $159(94)$ & $119(75)$ & 171 & $\mathrm{n} / \mathrm{a}$ & 8 & 4.7 & [237] \\
\hline \multirow[t]{2}{*}{ mouse } & $\begin{array}{l}\text { TSA } 50 \mathrm{nM} / 8 \mathrm{~h}+ \\
\text { vitamin } C 57 \times 40^{4} \mathrm{nM} / 7 \mathrm{~h}\end{array}$ & \multirow[t]{2}{*}{ embryos } & 61 & $\mathrm{n} / \mathrm{a}$ & $51(83.6)$ & 105 & $\mathrm{n} / \mathrm{a}$ & 16 & 15.2 & \multirow[t]{2}{*}{ [150] } \\
\hline & Control & & 94 & $\mathrm{n} / \mathrm{a}$ & $34(36.2)$ & 178 & $\mathrm{n} / \mathrm{a}$ & 0 & 0 & \\
\hline \multirow[t]{4}{*}{ mouse } & Vitamin $\mathrm{C} 1 \times 10^{5} \mathrm{nM} / 16 \mathrm{~h}$ & \multirow[t]{4}{*}{ embryos } & 194 & $174(89.7)$ & $101(52.1)$ & 206 & $\mathrm{n} / \mathrm{a}$ & 8 & 3.9 & \multirow[t]{4}{*}{ [148] } \\
\hline & PsA $1 \times 10^{4} \mathrm{nM} / 16 \mathrm{~h}$ & & 201 & $166(82.6)$ & $83(41.3)$ & 261 & $\mathrm{n} / \mathrm{a}$ & 8 & 3.1 & \\
\hline & Vitamin $C+\operatorname{PsA} / 16 \mathrm{~h}$ & & 193 & $164(85.0)$ & $109(56.5)$ & 203 & $\mathrm{n} / \mathrm{a}$ & 10 & 4.9 & \\
\hline & Control & & 224 & $181(80.8)$ & $102(45.5)$ & 258 & $\begin{array}{l}\mathrm{n} / \mathrm{a} \\
\mathrm{n} / \mathrm{a}\end{array}$ & 0 & $\begin{array}{c}4.9 \\
0\end{array}$ & \\
\hline \multirow[t]{3}{*}{ mouse } & $\begin{array}{l}\text { Dux overexpression }+ \\
\text { DNMT3A/3B knockdown }\end{array}$ & \multirow[t]{3}{*}{ embryos } & 56 & $51(91.1)$ & $\mathrm{n} / \mathrm{a}$ & 43 & $\mathrm{n} / \mathrm{a}$ & 8 & 18.6 & \multirow[t]{3}{*}{ [241] } \\
\hline & Kdm4d mRNA injection + & & 58 & $54(93.1)$ & $\mathrm{n} / \mathrm{a}$ & 49 & $\mathrm{n} / \mathrm{a}$ & 6 & 12.2 & \\
\hline & $\begin{array}{l}\text { Control } \\
\text { C knockdown }\end{array}$ & & 116 & $109(94.0)$ & $\mathrm{n} / \mathrm{a}$ & 99 & $\mathrm{n} / \mathrm{a}$ & 1 & 1.0 & \\
\hline cattle & $\begin{array}{l}\text { TSA 50nM/10 h } \\
\text { Control }\end{array}$ & embryos & $\begin{array}{l}237 \\
198\end{array}$ & $\begin{array}{l}222(93.7) \\
193(97.5)\end{array}$ & $\begin{array}{c}103(43.5) \\
63(31.8)\end{array}$ & $\begin{array}{l}36 \\
18\end{array}$ & $\begin{array}{c}6 / 13(46.2) \\
0 / 7(0)\end{array}$ & $\begin{array}{l}3 \\
0\end{array}$ & $\begin{array}{c}8.3 \\
0\end{array}$ & [114] \\
\hline buffalo & $\begin{array}{l}\text { DKK1 } 100 \mathrm{ng} / \mathrm{mL} \\
\text { Control }\end{array}$ & embryos & $\begin{array}{l}431 \\
388\end{array}$ & $\begin{array}{l}\mathrm{n} / \mathrm{a} \\
\mathrm{n} / \mathrm{a}\end{array}$ & $\begin{array}{l}182(42.6) \\
152(39.0)\end{array}$ & $\begin{array}{l}26 \\
24\end{array}$ & $\begin{array}{l}4 / 13(30.8) \\
0 / 12(0)\end{array}$ & $\begin{array}{l}2 \\
0\end{array}$ & $\begin{array}{c}5.5 \\
0\end{array}$ & [234] \\
\hline
\end{tabular}


Table 1. Cont.

\begin{tabular}{|c|c|c|c|c|c|c|c|c|c|c|}
\hline Species & Modifier & $\begin{array}{l}\text { Treatment } \\
\text { on }\end{array}$ & $\begin{array}{l}\text { No. of } \\
\text { Reconstructed } \\
\text { Embryo }\end{array}$ & $\begin{array}{l}\text { No. of } \\
\text { 2-Cell (\%) }\end{array}$ & $\begin{array}{c}\text { No. of } \\
\text { Blastocyst (\%) }\end{array}$ & $\begin{array}{l}\text { No. of Embryo } \\
\text { Transferred }\end{array}$ & $\begin{array}{c}\text { No. of } \\
\text { Pregnant/ } \\
\text { Recipient (\%) }\end{array}$ & $\begin{array}{l}\text { No. of } \\
\text { Offspring }\end{array}$ & $\begin{array}{c}\text { Birth Rate per } \\
\text { Embryo } \\
\text { Transferred (\%) }\end{array}$ & Reference \\
\hline \multirow{2}{*}{$\begin{array}{l}\text { cynomolgus } \\
\text { monkey }\end{array}$} & \multirow{2}{*}{$\begin{array}{l}\text { KDM4D mRNA injection + TSA } \\
10 \mathrm{nM} / 10 \mathrm{~h} \\
\text { Control }\end{array}$} & \multirow[t]{2}{*}{ embryos } & 38 & $\mathrm{n} / \mathrm{a}$ & 17 (44.7) & 79 & $6 / 21(28.6)$ & 2 & 2.5 & \multirow[t]{2}{*}{ [103] } \\
\hline & & & 30 & $\mathrm{n} / \mathrm{a}$ & $4(13.8)$ & $\mathrm{n} / \mathrm{a}$ & $\mathrm{n} / \mathrm{a}$ & $\mathrm{n} / \mathrm{a}$ & $\mathrm{n} / \mathrm{a}$ & \\
\hline minipig & $\begin{array}{l}\text { Scriptaid } 500 \mathrm{nM} / 14-16 \mathrm{~h} \\
\text { Control }\end{array}$ & embryos & $\begin{array}{l}155 \\
171\end{array}$ & $\begin{array}{l}134(86.0) \\
148(87.0)\end{array}$ & $\begin{array}{l}33(21.0) \\
16(9.0)\end{array}$ & $\begin{array}{l}1610 \\
1389\end{array}$ & $\begin{array}{l}8 / 10(80.0) \\
1 / 9(11.1)\end{array}$ & $\begin{array}{c}21 \\
3 \text { mummies }\end{array}$ & $\begin{array}{c}1.3 \\
0\end{array}$ & [118] \\
\hline pig & $\begin{array}{l}\text { Abexinostat } 0.5 \mathrm{nM} / 6 \mathrm{~h} \\
\text { Control }\end{array}$ & embryos & $\begin{array}{l}106 \\
106\end{array}$ & $\begin{array}{l}94(89.0) \\
90(85.0)\end{array}$ & $\begin{array}{l}27(25.2) \\
11(10.2)\end{array}$ & $\begin{array}{l}782 \\
\mathrm{n} / \mathrm{a}\end{array}$ & $\begin{array}{c}1 / 3(33.3) \\
n / a\end{array}$ & $\begin{array}{l}2 \text { fetuses } \\
\mathrm{n} / \mathrm{a}\end{array}$ & $\begin{array}{c}0 \\
\mathrm{n} / \mathrm{a}\end{array}$ & [128] \\
\hline pig & $\begin{array}{l}\text { BIX-01294 } 50 \mathrm{nM} / 14-16 \mathrm{~h} \\
\text { Control }\end{array}$ & embryos & $\begin{array}{l}336 \\
470\end{array}$ & $\begin{array}{l}295(87.8) \\
416(88.5)\end{array}$ & $\begin{array}{l}78(23.2) \\
77(16.4)\end{array}$ & $\begin{array}{l}506 \\
503\end{array}$ & $\begin{array}{l}2 / 3(66.7) \\
1 / 3(33.3)\end{array}$ & $\begin{array}{c}15 \\
8\end{array}$ & $\begin{array}{l}3.0 \\
1.6\end{array}$ & [167] \\
\hline pig & $\begin{array}{l}\text { Vitamin C } 2.8 \times 10^{5} \mathrm{nM} / 15 \mathrm{~h} \\
\text { Control }\end{array}$ & embryos & $\begin{array}{l}74 \\
95\end{array}$ & $\begin{array}{l}71(95.9) \\
85(89.5)\end{array}$ & $\begin{array}{l}25(33.8) \\
12(12.6)\end{array}$ & $\begin{array}{l}5180 \\
3885\end{array}$ & $\begin{array}{l}9 / 20(45.0) \\
5 / 15(33.3)\end{array}$ & $\begin{array}{l}9 \\
1\end{array}$ & $\begin{array}{c}0.2 \\
0.03\end{array}$ & [146] \\
\hline goat & $\begin{array}{l}\text { PGC7 overexpression } \\
\text { Control }\end{array}$ & $\begin{array}{l}\text { donor } \\
\text { cells }\end{array}$ & $\begin{array}{l}\mathrm{n} / \mathrm{a} \\
\mathrm{n} / \mathrm{a}\end{array}$ & $\begin{array}{l}\mathrm{n} / \mathrm{a} \\
\mathrm{n} / \mathrm{a}\end{array}$ & $\begin{array}{l}\mathrm{n} / \mathrm{a} \\
\mathrm{n} / \mathrm{a}\end{array}$ & $\begin{array}{l}300 \\
240\end{array}$ & $\begin{array}{l}14 / 30(46.7) \\
8 / 24(33.3)\end{array}$ & $\begin{array}{c}21 \\
8\end{array}$ & $\begin{array}{l}7.0 \\
3.3\end{array}$ & [194] \\
\hline
\end{tabular}




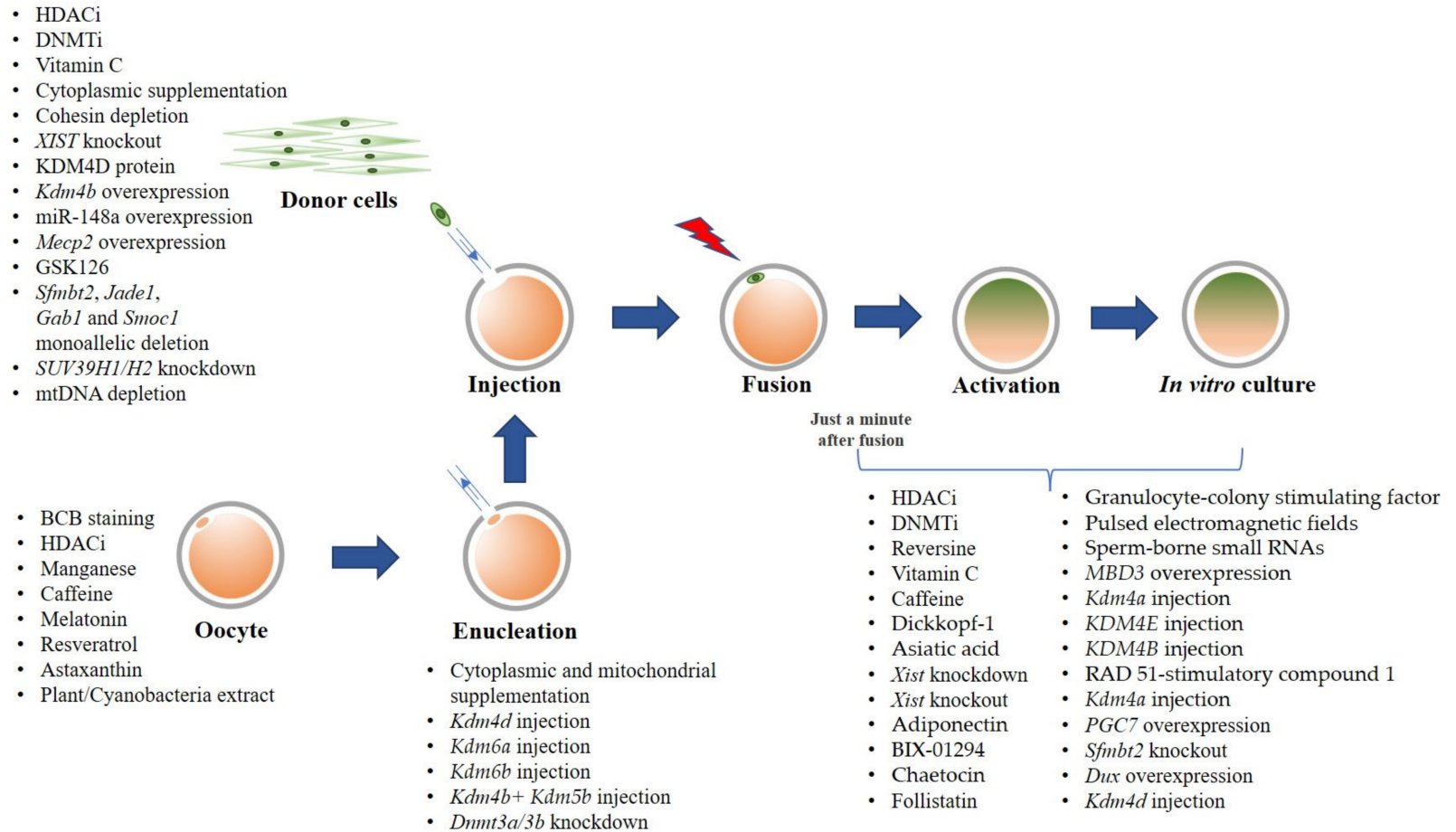

Figure 1. Summary of strategies for cloning efficiency improvement.

Author Contributions: Conceptualization, K.S. and R.P.; Writing-Original Draft Preparation, K.S.; Writing-Review and Editing, K.S., M.K. and R.P. Visualization, K.S. All authors have read and agreed to the published version of the manuscript.

Funding: This work was supported by (i) Suranaree University of Technology (SUT), (ii) Thailand Science Research and Innovation (TSRI), and (iii) National Science, Research and Innovation Fund (NSRF) (project code 90464).

Institutional Review Board Statement: Not applicable.

Informed Consent Statement: Not applicable.

Acknowledgments: K.S. was supported by the SUT Postdoctoral Research Fellowship.

Conflicts of Interest: The authors declare no conflict of interest. The funders had no role in the writing of the manuscript, or in the decision to publish the manuscript.

\section{References}

1. Wilmut, I.; Schnieke, A.E.; McWhir, J.; Kind, A.J.; Campbell, K.H.S. Viable offspring derived from fetal and adult mammalian cells. Nature 1997, 385, 810-813. [CrossRef] [PubMed]

2. Samiec, M.; Skrzyszowska, M. Extranuclear inheritance of mitochondrial genome and epigenetic reprogrammability of chromosomal telomeres in somatic cell cloning of mammals. Int. J. Mol. Sci. 2021, 22, 3099. [CrossRef] [PubMed]

3. Loi, P.; Iuso, D.; Czernik, M.; Ogura, A. A New, Dynamic Era for Somatic Cell Nuclear Transfer? Trends Biotechnol. 2016, 34, 791-797. [CrossRef]

4. Vajta, G. Cloning: A Sleeping Beauty Awaiting the Kiss? Cell. Reprogram. 2018, 20, 145-156. [CrossRef]

5. Long, C.R.; Westhusin, M.E.; Golding, M.C. Reshaping the transcriptional frontier: Epigenetics and somatic cell nuclear transfer. Mol. Reprod. Dev. 2014, 81, 183-193. [CrossRef] [PubMed]

6. Zhang, X.; Gao, S.; Liu, X. Advance in the role of epigenetic reprogramming in somatic cell nuclear transfer-mediated embryonic development. Stem Cells Int. 2021, 2021, 6681337. [CrossRef]

7. Young, L.E.; Sinclair, K.D.; Wilmut, I. Large offspring syndrome in cattle and sheep. Rev. Reprod. 1998, 3, 155-163. [CrossRef] 
8. Niemann, H.; Wrenzycki, C.; Lucas-Hahn, A.; Brambrink, T.; Kues, W.A.; Carnwath, J.W. Gene expression patterns in bovine in vitro-produced and nuclear transfer-derived embryos and their implications for early development. Cloning Stem Cells 2002, 4, 29-38. [CrossRef]

9. Constant, F.; Guillomot, M.; Heyman, Y.; Vignon, X.; Laigre, P.; Servely, J.L.; Renard, J.P.; Chavatte-Palmer, P. Large offspring or large placenta syndrome? Morphometric analysis of late gestation bovine placentomes from somatic nuclear transfer pregnancies complicated by hydrallantois. Biol. Reprod. 2006, 75, 122-130. [CrossRef]

10. Loi, P.; Czernik, M.; Zacchini, F.; Iuso, D.; Scapolo, P.A.; Ptak, G. Sheep: The first large animal model in nuclear transfer research. Cell. Reprogram. 2013, 15, 367-373. [CrossRef]

11. Ogura, A.; Inoue, K.; Wakayama, T. Recent advancements in cloning by somatic cell nuclear transfer. Philos. Trans. R. Soc. Lond. B. Biol. Sci. 2013, 368, 20110329. [CrossRef] [PubMed]

12. Tian, X.; Kubota, C.; Enright, B.; Yang, X. Cloning animals by somatic cell nuclear transfer-Biological factors. Reprod. Biol. Endocrinol. 2003, 1, 98. [CrossRef] [PubMed]

13. Yang, X.; Smith, S.; Tian, X.; Lewin, H.; Renard, J.-P.; Wakayama, T. Nuclear reprogramming of cloned embryos and its implications for therapeutic cloning. Nat. Genet. 2007, 39, 295-302. [CrossRef] [PubMed]

14. Samiec, M.; Skrzyszowska, M. Can reprogramming of overall epigenetic memory and specific parental genomic imprinting memory within donor cell-inherited nuclear genome be a major hindrance for the somatic cell cloning of mammals?-A review. Ann. Anim. Sci. 2018, 18, 623-638. [CrossRef]

15. Simmet, K.; Wolf, E.; Zakhartchenko, V. Manipulating the epigenome in nuclear transfer cloning: Where, when and how. Int. J. Mol. Sci. 2020, 22, 236. [CrossRef]

16. Selokar, N.L.; Saini, M.; Palta, P.; Chauhan, M.S.; Manik, R.S.; Singla, S.K. Cloning of buffalo, a highly valued livestock species of South and Southeast Asia: Any achievements? Cell. Reprogram. 2018, 20, 89-98. [CrossRef]

17. Wang, X.; Qu, J.; Li, J.; He, H.; Liu, Z.; Huan, Y. Epigenetic reprogramming during somatic cell nuclear transfer: Recent progress and future directions. Front. Genet. 2020, 11, 205. [CrossRef]

18. Klinger, B.; Schnieke, A. Twenty-five years after Dolly-How far have we come? Reproduction 2021, 162, F1-F10. [CrossRef]

19. Jullien, J.; Pasque, V.; Halley-Stott, R.P.; Miyamoto, K.; Gurdon, J.B. Mechanisms of nuclear reprogramming by eggs and oocytes: A deterministic process? Nat. Rev. Mol. Cell Biol. 2011, 12, 453-459. [CrossRef]

20. Wilmut, I.; Beaujean, N.; de Sousa, P.A.; Dinnyes, A.; King, T.J.; Paterson, L.A.; Wells, D.N.; Young, L.E. Somatic cell nuclear transfer. Nature 2002, 419, 583-586. [CrossRef]

21. Niemann, H. Epigenetic reprogramming in mammalian species after SCNT-based cloning. Theriogenology 2016, 86, 80-90. [CrossRef]

22. Sproul, D.; Gilbert, N.; Bickmore, W.A. The role of chromatin structure in regulating the expression of clustered genes. Nat. Rev. Genet. 2005, 6, 775-781. [CrossRef]

23. Enright, B.P.; Sung, L.Y.; Chang, C.C.; Yang, X.; Tian, X.C. Methylation and acetylation characteristics of cloned bovine embryos from donor cells treated with 5-aza-2'-deoxycytidine. Biol. Reprod. 2005, 72, 944-948. [CrossRef]

24. Smith, Z.D.; Meissner, A. DNA methylation: Roles in mammalian development. Nat. Rev. Genet. 2013, 14, 204-220. [CrossRef]

25. Guo, J.U.; Su, Y.; Zhong, C.; Ming, G.L.; Song, H. Emerging roles of TET proteins and 5-hydroxymethylcytosines in active DNA demethylation and beyond. Cell Cycle 2011, 10, 2662-2668. [CrossRef] [PubMed]

26. Iager, A.; Ragina, N.; Ross, P.; Beyhan, Z.; Cunniff, K.; Rodriguez, R.; Cibelli, J. Trichostatin A improves histone acetylation in bovine somatic cell nuclear transfer early embryos. Cloning Stem Cells 2008, 10, 371-379. [CrossRef] [PubMed]

27. Shi, L.H.; Ai, J.S.; OuYang, Y.C.; Huang, J.C.; Lei, Z.L.; Wang, Q.; Yin, S.; Han, Z.M.; Sun, Q.Y.; Chen, D.Y. Trichostatin A and nuclear reprogramming of cloned rabbit embryos. J. Anim. Sci. 2008, 86, 1106-1113. [CrossRef] [PubMed]

28. Li, J.; Svarcova, O.; Villemoes, K.; Kragh, P.M.; Schmidt, M.; Bøgh, I.B.; Zhang, Y.; Du, Y.; Lin, L.; Purup, S.; et al. High in vitro development after somatic cell nuclear transfer and trichostatin A treatment of reconstructed porcine embryos. Theriogenology 2008, 70, 800-808. [CrossRef]

29. Sun, J.-M.; Spencer, V.A.; Chen, H.Y.; Li, L.; Davie, J.R. Measurement of histone acetyltransferase and histone deacetylase activities and kinetics of histone acetylation. Methods 2003, 31, 12-23. [CrossRef]

30. Kubota, C.; Yang, X.; Dinnyes, A.; Todoroki, J.; Yamakuchi, H.; Mizoshita, K.; Inohae, S.; Tabara, N. In vitro and in vivo survival of frozen-thawed bovine oocytes after IVF, nuclear transfer, and parthenogenetic activation. Mol. Reprod. Dev. 1998, 51, 281-286. [CrossRef]

31. Liu, L.; Oldenbourg, R.; Trimarchi, J.R.; Keefe, D.L. A reliable, noninvasive technique for spindle imaging and enucleation of mammalian oocytes. Nat. Biotechnol. 2000, 18, 223-225. [CrossRef]

32. Zhao, Q.; Qiu, J.; Feng, Z.; Du, Y.; Liu, Y.; Zhao, Z.; Sun, M.; Cui, M.; Zhao, X. Robotic label-free precise oocyte enucleation for improving developmental competence of cloned embryos. IEEE Trans. Biomed. Eng. 2021, 68, 2348-2359. [CrossRef] [PubMed]

33. Wakayama, T.; Perry, A.; Zuccotti, M.; Johnson, K.; Yanagimachi, R. Full-term development of mice from enucleated oocytes injected with cumulus cell nuclei. Nature 1998, 394, 369-374. [CrossRef] [PubMed]

34. McGrath, J.; Solter, D. Nuclear transplantation in the mouse embryo by microsurgery and cell fusion. Science 1983, 220, 1300-1302. [CrossRef] [PubMed]

35. Ono, Y.; Shimozawa, N.; Muguruma, K.; Kimoto, S.; Hioki, K.; Tachibana, M.; Shinkai, Y.; Ito, M.; Kono, T. Production of cloned mice from embryonic stem cells arrested at metaphase. Reproduction 2001, 122, 731-736. [CrossRef] 
36. Vajta, G. Handmade cloning: The future way of nuclear transfer? Trends Biotechnol. 2007, 25, 250-253. [CrossRef]

37. Vajta, G.; Lewis, I.M.; Trounson, A.O.; Purup, S.; Maddox-Hyttel, P.; Schmidt, M.; Pedersen, H.G.; Greve, T.; Callesen, H. Handmade somatic cell cloning in cattle: Analysis of factors contributing to high efficiency in vitro. Biol. Reprod. 2003, 68, 571-578. [CrossRef]

38. Tecirlioglu, R.T.; French, A.J.; Lewis, I.M.; Vajta, G.; Korfiatis, N.A.; Hall, V.J.; Ruddock, N.T.; Cooney, M.A.; Trounson, A.O. Birth of a cloned calf derived from a vitrified hand-made cloned embryo. Reprod. Fertil. Dev. 2003, 15, 361-366. [CrossRef] [PubMed]

39. Oback, B.; Wiersema, A.T.; Gaynor, P.; Laible, G.; Tucker, F.C.; Oliver, J.E.; Miller, A.L.; Troskie, H.E.; Wilson, K.L.; Forsyth, J.T.; et al. Cloned cattle derived from a novel zona-free embryo reconstruction system. Cloning Stem Cells 2003, 5, 3-12. [CrossRef]

40. Lagutina, I.; Lazzari, G.; Duchi, R.; Colleoni, S.; Ponderato, N.; Turini, P.; Crotti, G.; Galli, C. Somatic cell nuclear transfer in horses: Effect of oocyte morphology, embryo reconstruction method and donor cell type. Reproduction 2005, 130, 559-567. [CrossRef]

41. Du, Y.; Kragh, P.M.; Zhang, Y.; Li, J.; Schmidt, M.; Bøgh, I.B.; Zhang, X.; Purup, S.; Jørgensen, A.L.; Pedersen, A.M.; et al. Piglets born from handmade cloning, an innovative cloning method without micromanipulation. Theriogenology 2007, 68, 1104-1110. [CrossRef] [PubMed]

42. George, A.; Sharma, R.; Singh, K.P.; Panda, S.K.; Singla, S.K.; Palta, P.; Manik, R.; Chauhan, M.S. Production of cloned and transgenic embryos using buffalo (Bubalus bubalis) embryonic stem cell-like cells isolated from in vitro fertilized and cloned blastocysts. Cell Reprogram. 2011, 13, 263-272. [CrossRef] [PubMed]

43. Zhang, P.; Liu, P.; Dou, H.; Chen, L.; Chen, L.; Lin, L.; Tan, P.; Vajta, G.; Gao, J.; Du, Y.; et al. Handmade cloned transgenic sheep rich in omega-3 Fatty acids. PLoS ONE 2013, 8, e55941. [CrossRef]

44. Moulavi, F.; Asadi-Moghadam, B.; Omidi, M.; Yarmohammadi, M.; Ozegovic, M.; Rastegar, A.; Hosseini, S.M. Pregnancy and calving rates of cloned dromedary camels produced by conventional and handmade cloning techniques and in vitro and in vivo matured oocytes. Mol. Biotechnol. 2020, 62, 433-442. [CrossRef]

45. Hosseini, S.M.; Hajian, M.; Moulavi, F.; Asgari, V.; Forouzanfar, M.; Nasr-Esfahani, M.H. Cloned sheep blastocysts derived from oocytes enucleated manually using a pulled pasteur pipette. Cell Reprogram. 2013, 15, 15-23. [CrossRef]

46. Hosseini, S.M.; Moulavi, F.; Asgari, V.; Shirazi, A.; Abazari-Kia, A.H.; Ghanaei, H.R.; Nasr-Esfahani, M.H. Simple, fast, and efficient method of manual oocyte enucleation using a pulled Pasteur pipette. In Vitro Cell. Dev. Biol. Anim. 2013, 49, 569-575. [CrossRef] [PubMed]

47. Lee, E.J.; Ji, K.B.; Lee, J.H.; Oh, H.J.; Kil, T.Y.; Kim, M.K. Application of the modified handmade cloning technique to pigs. J. Anim. Sci. Technol. 2021, 63, 281-294. [CrossRef]

48. Hosseini, S.M.; Hajian, M.; Forouzanfar, M.; Ostadhosseini, S.; Moulavi, F.; Ghanaei, H.R.; Gourbai, H.; Shahverdi, A.H.; Vosough A.D.; Nasr-Esfahani, M.H. Chemically assisted somatic cell nuclear transfer without micromanipulator in the goat: Effects of demecolcine, cytochalasin-B, and MG-132 on the efficiency of a manual method of oocyte enucleation using a pulled Pasteur pipette. Anim. Reprod. Sci. 2015, 158, 11-18. [CrossRef]

49. Cortez, J.V.; Vajta, G.; Valderrama, N.M.; Portocarrero, G.S.; Quintana, J.M. High pregnancy and calving rates with a limited number of transferred handmade cloned bovine embryos. Cell. Reprogram. 2018, 20, 4-8. [CrossRef]

50. Moulavi, F.; Hosseini, S.M. Development of a modified method of handmade cloning in dromedary camel. PLoS ONE 2019, 14, e0213737. [CrossRef] [PubMed]

51. Ericsson, S.A.; Boice, M.L.; Funahashi, H.; Day, B.N. Assessment of porcine oocytes using brilliant cresyl blue. Theriogenology 1993, 39, 214. [CrossRef]

52. Mangia, F.; Epstein, C.J. Biochemical studies of growing mouse oocytes: Preparation of oocytes and analysis of glucose-6phosphate dehydrogenase and lactate dehydrogenase activities. Dev. Biol. 1975, 45, 211-220. [CrossRef]

53. Bhojwani, S.; Alm, H.; Torner, H.; Kanitz, W.; Poehland, R. Selection of developmentally competent oocytes through brilliant cresyl blue stain enhances blastocyst development rate after bovine nuclear transfer. Theriogenology 2007, 67, 341-345. [CrossRef] [PubMed]

54. Su, J.; Wang, Y.; Li, R.; Peng, H.; Hua, S.; Li, Q.; Quan, F.; Guo, Z.; Zhang, Y. Oocytes selected using BCB staining enhance nuclear reprogramming and the in vivo development of SCNT embryos in cattle. PLoS ONE 2012, 7, e36181. [CrossRef] [PubMed]

55. Rodríguez-González, E.; López-Béjar, M.; Velilla, E.; Paramio, M.T. Selection of prepubertal goat oocytes using the brilliant cresyl blue test. Theriogenology 2002, 57, 1397-1409. [CrossRef]

56. Mohammadi-Sangcheshmeh, A.; Held, E.; Ghanem, N.; Rings, F.; Salilew-Wondim, D.; Tesfaye, D.; Sieme, H.; Schellander, K.; Hoelker, M. G6PDH-activity in equine oocytes correlates with morphology, expression of candidate genes for viability, and preimplantative in vitro development. Theriogenology 2011, 76, 1215-1226. [CrossRef]

57. El Shourbagy, S.H.; Spikings, E.C.; Freitas, M.; St. John, J.C. Mitochondria directly influence fertilisation outcome in the pig Reproduction 2006, 131, 233-245. [CrossRef]

58. Cagnone, G.L.; Tsai, T.-S.S.; Makanji, Y.; Matthews, P.; Gould, J.; Bonkowski, M.S.; Elgass, K.D.; Wong, A.S.; Wu, L.E.; McKenzie, M.; et al. Restoration of normal embryogenesis by mitochondrial supplementation in pig oocytes exhibiting mitochondrial DNA deficiency. Sci. Rep. 2016, 6, 23229. [CrossRef]

59. Catalá, M.G.; Izquierdo, D.; Uzbekova, S.; Morató, R.; Roura, M.; Romaguera, R.; Papillier, P.; Paramio, M.T. Brilliant cresyl blue stain selects largest oocytes with highest mitochondrial activity, maturation-promoting factor activity and embryo developmental competence in prepubertal sheep. Reproduction 2011, 142, 517-527. [CrossRef] 
60. Wang, L.; Lin, J.; Huang, J.; Wang, J.; Zhao, Y.; Chen, T. Selection of ovine oocytes by brilliant cresyl blue staining. J. Biomed. Biotechnol. 2012, 2012, 7. [CrossRef]

61. Mohapatra, S.K.; Sandhu, A.; Neerukattu, V.S.; Singh, K.P.; Selokar, N.L.; Singla, S.K.; Chauhan, M.S.; Manik, R.S.; Palta, P. Buffalo embryos produced by handmade cloning from oocytes selected using brilliant cresyl blue staining have better developmental competence and quality and are closer to embryos produced by in vitro fertilization in terms of their epigenetic status and gene expression pattern. Cell Reprogram. 2015, 17, 141-150. [PubMed]

62. Sadeesh, E.M.; Fozia, S.; Meena, K. Combined positive effect of oocyte extracts and brilliant cresyl blue stained recipient cytoplasts on epigenetic reprogramming and gene expression in buffalo nuclear transfer embryos. Cytotechnology 2017, 69, 289-305. [CrossRef] [PubMed]

63. Jia, L.; Ding, B.; Shen, C.; Luo, S.; Zhang, Y.; Zhou, L.; Ding, R.; Qu, P.; Liu, E. Use of oocytes selected by brilliant cresyl blue staining enhances rabbit cloned embryo development in vitro. Zygote 2019, 27, 166-172. [CrossRef] [PubMed]

64. Wu, Y.-G.; Liu, Y.; Zhou, P.; Lan, G.-C.; Han, D.; Miao, D.-Q.; Tan, J.-H. Selection of oocytes for in vitro maturation by brilliant cresyl blue staining: A study using the mouse model. Cell Res. 2007, 17, 722-731. [CrossRef] [PubMed]

65. Alcoba, D.D.; da Rosa Braga, B.L.; Sandi-Monroy, N.L.; Proença, L.A.; Felix Lopes, R.F.; de Oliveira, A.T. Selection of Rattus norvegicus oocytes for in vitro maturation by brilliant cresyl blue staining. Zygote 2013, 21, 238-245. [CrossRef] [PubMed]

66. Rodrigues, B.A.; Rodriguez, P.; Silva, A.E.F.; Cavalcante, L.F.; Feltrin, C.; Rodrigues, J.L. Preliminary study in immature canine oocytes stained with brilliant cresyl blue and obtained from bitches with low and high progesterone serum profiles. Reprod. Domest. Anim. 2009, 44, 255-258. [CrossRef] [PubMed]

67. Jewgenow, K.; Fernandez-Gonzalez, L.; Jänsch, S.; Viertel, D.; Zahmel, J. Brilliant cresyl blue staining allows the selection for developmentally competent immature feline oocytes. Theriogenology 2019, 126, 320-325. [CrossRef] [PubMed]

68. Piras, A.R.; Ariu, F.; Zedda, M.T.; Paramio, M.T.; Bogliolo, L. Selection of immature cat oocytes with brilliant cresyl blue stain improves in vitro embryo production during non-breeding season. Animals 2020, 10, 1496. [CrossRef]

69. Fathi, M.; Ashry, M.; Salama, A.; Badr, M.R. Developmental competence of dromedary camel (Camelus dromedarius) oocytes selected using brilliant cresyl blue staining. Zygote 2017, 25, 529-536. [CrossRef]

70. Duarte Alcoba, D.; Gonsales Valério, E.; Conzatti, M.; Schneider, J.; Capp, E.; von Eye Corleta, H.; Brum, I.S. Selection of developmentally competent human oocytes aspirated during cesarean section. J. Matern. Fetal Neonatal Med. 2018, 31, 735-739. [CrossRef] [PubMed]

71. Fu, B.; Ren, L.; Liu, D.; Ma, J.-Z.; An, T.-Z.; Yang, X.-Q.; Ma, H.; Zhang, D.-J.; Guo, Z.-H.; Guo, Y.-Y.; et al. Subcellular characterization of porcine oocytes with different glucose-6-phosphate dehydrogenase activities. Asian-Australas. J. Anim. Sci. 2015, 28, 1703-1712. [CrossRef] [PubMed]

72. Zhai, Y.; Li, W.; Zhang, Z.; Cao, Y.; Wang, Z.; Zhang, S.; Li, Z. Epigenetic states of donor cells significantly affect the development of somatic cell nuclear transfer (SCNT) embryos in pigs. Mol. Reprod. Dev. 2018, 85, 26-37. [CrossRef] [PubMed]

73. Gouveia, C.; Huyser, C.; Egli, D.; Pepper, M.S. Lessons learned from somatic cell nuclear transfer. Int. J. Mol. Sci. 2020, 21, 2314. [CrossRef] [PubMed]

74. Peura, T.T.; Lewis, I.M.; Trounson, A.O. The effect of recipient oocyte volume on nuclear transfer in cattle. Mol. Reprod. Dev. 1998, 50, 185-191. [CrossRef]

75. Ribeiro, E.S.; Gerger, R.P.; Ohlweiler, L.U.; Ortigari, I., Jr.; Mezzalira, J.C.; Forell, F.; Bertolini, L.R.; Rodrigues, J.L.; Ambrósio, C.E.; Miglino, M.A.; et al. Developmental potential of bovine hand-made clone embryos reconstructed by aggregation or fusion with distinct cytoplasmic volumes. Cloning Stem Cells 2009, 11, 377-386. [CrossRef]

76. Xu, L.; Mesalam, A.; Lee, K.L.; Song, S.H.; Khan, I.; Chowdhury, M.M.R.; Lv, W.; Kong, I.K. Improves the in vitro developmental competence and reprogramming efficiency of cloned bovine embryos by additional complimentary cytoplasm. Cell. Reprogram. 2019, 21, 51-60. [CrossRef]

77. Song, S.H.; Oh, S.H.; Xu, L.; Lee, K.L.; Hwang, J.Y.; Joo, M.D.; Kong, I.K. Effect of additional cytoplasm of cloned embryo on in vitro developmental competence and reprogramming efficiency in mice. Cell. Reprogram. 2020, 22, 236-243. [CrossRef]

78. Song, S.H.; Lee, K.L.; Xu, L.; Joo, M.D.; Hwang, J.Y.; Oh, S.H.; Kong, I.K. Production of cloned cats using additional complimentary cytoplasm. Anim. Reprod. Sci. 2019, 208, 106125. [CrossRef]

79. Lee, W.J.; Lee, J.H.; Jeon, R.H.; Jang, S.J.; Lee, S.C.; Park, J.S.; Lee, S.L.; King, W.A.; Rho, G.J. Supplement of autologous ooplasm into porcine somatic cell nuclear transfer embryos does not alter embryo development. Reprod. Domest. Anim. 2017, 52, 437-445. [CrossRef]

80. Srirattana, K.; St John, J.C. Transmission of dysfunctional mitochondrial DNA and its implications for mammalian reproduction. Adv. Anat. Embryol. Cell Biol. 2019, 231, 75-103. [PubMed]

81. Srirattana, K.; St. John, J.C. Additional mitochondrial DNA influences the interactions between the nuclear and mitochondrial genomes in a bovine embryo model of nuclear transfer. Sci. Rep. 2018, 8, 7246. [CrossRef] [PubMed]

82. Ferreira, A.F.; Soares, M.; Almeida Reis, S.; Ramalho-Santos, J.; Sousa, A.P.; Almeida-Santos, T. Does supplementation with mitochondria improve oocyte competence? A systematic review. Reproduction 2021, 161, 269-287. [CrossRef]

83. Sekirina, G.G.; Bogoliubova, N.A.; Antonova, N.V.; Dyban, A.P. The behaviour of mitochondria and cell integration during somatic hybridisation of sister blastomeres of the 2-cell mouse embryo. Zygote 1997, 5, 97-103. [CrossRef] 
84. Takeda, K.; Akagi, S.; Kaneyama, K.; Kojima, T.; Takahashi, S.; Imai, H.; Yamanaka, M.; Onishi, A.; Hanada, H. Proliferation of donor mitochondrial DNA in nuclear transfer calves (Bos taurus) derived from cumulus cells. Mol. Reprod. Dev. 2003, 64, 429-437. [CrossRef]

85. Evans, M.J.; Gurer, C.; Loike, J.D.; Wilmut, I.; Schnieke, A.E.; Schon, E.A. Mitochondrial DNA genotypes in nuclear transferderived cloned sheep. Nat. Genet. 1999, 23, 90-93. [CrossRef]

86. Takeda, K.; Takahashi, S.; Onishi, A.; Goto, Y.; Miyazawa, A.; Imai, H. Dominant distribution of mitochondrial DNA from recipient oocytes in bovine embryos and offspring after nuclear transfer. J. Reprod. Fertil. 1999, 116, 253-259. [CrossRef] [PubMed]

87. Steinborn, R.; Schinogl, P.; Zakhartchenko, V.; Achmann, R.; Schernthaner, W.; Stojkovic, M.; Wolf, E.; Müller, M.; Brem, G. Mitochondrial DNA transmission in cattle cloned by nuclear transfer of adult and fetal cells. Cloning 2000, 2, 157.

88. Burgstaller, J.; Schinogl, P.; Dinnyes, A.; Müller, M.; Steinborn, R. Mitochondrial DNA heteroplasmy in ovine fetuses and sheep cloned by somatic cell nuclear transfer. BMC Dev. Biol. 2007, 7, 141. [CrossRef]

89. Do, M.; Jang, W.-G.; Hwang, J.; Jang, H.; Kim, E.-J.; Jeong, E.-J.; Shim, H.; Hwang, S.; Oh, K.; Byun, S.; et al. Inheritance of mitochondrial DNA in serially recloned pigs by somatic cell nuclear transfer (SCNT). Biochem. Biophys. Res. Commun. 2012, 424, 765-770. [CrossRef] [PubMed]

90. Bowles, E.J.; Tecirlioglu, R.T.; French, A.J.; Holland, M.K.; St. John, J.C. Mitochondrial DNA transmission and transcription after somatic cell fusion to one or more cytoplasts. Stem Cells 2008, 26, 775-782. [CrossRef] [PubMed]

91. Chen, D.-Y.; Wen, D.-C.; Zhang, Y.-P.; Sun, Q.-Y.; Han, Z.-M.; Liu, Z.-H.; Shi, P.; Li, J.-S.; Xiangyu, J.-G.; Lian, L.; et al. Interspecies implantation and mitochondria fate of panda-rabbit cloned embryos. Biol. Reprod. 2002, 67, 637-642. [CrossRef]

92. Cortopassi, G.A.; Shibata, D.; Soong, N.W.; Arnheim, N. A pattern of accumulation of a somatic deletion of mitochondrial DNA in aging human tissues. Proc. Natl. Acad. Sci. USA 1992, 89, 7370-7374. [CrossRef] [PubMed]

93. Brierley, E.J.; Johnson, M.A.; Lightowlers, R.N.; James, O.F.W.; Turnbull, D.M. Role of mitochondrial DNA mutations in human aging: Implications for the central nervous system and muscle. Ann. Neurol. 1998, 43, 217-223. [CrossRef] [PubMed]

94. Srirattana, K.; St. John, J.C. Manipulating the mitochondrial genome to enhance cattle embryo development. G3 Genes Genomes Genet. 2017, 7, 2065. [CrossRef] [PubMed]

95. Kishigami, S.; Mizutani, E.; Ohta, H.; Hikichi, T.; Thuan, N.V.; Wakayama, S.; Bui, H.-T.T.; Wakayama, T. Significant improvement of mouse cloning technique by treatment with trichostatin A after somatic nuclear transfer. Biochem. Biophys. Res. Commun. 2006, 340, 183-189. [CrossRef]

96. Rybouchkin, A.; Kato, Y.; Tsunoda, Y. Role of histone acetylation in reprogramming of somatic nuclei following nuclear transfer. Biol. Reprod. 2006, 74, 1083-1089. [CrossRef]

97. Kishigami, S.; Bui, H.T.; Wakayama, S.; Tokunaga, K.; Van Thuan, N.; Hikichi, T.; Mizutani, E.; Ohta, H.; Suetsugu, R.; Sata, T.; et al. Successful mouse cloning of an outbred strain by trichostatin A treatment after somatic nuclear transfer. J. Reprod. Dev. 2007, 53, 165-170. [CrossRef]

98. Wang, F.; Kou, Z.; Zhang, Y.; Gao, S. Dynamic reprogramming of histone acetylation and methylation in the first cell cycle of cloned mouse embryos. Biol. Reprod. 2007, 77, 1007-1016. [CrossRef]

99. Sparman, M.L.; Tachibana, M.; Mitalipov, S.M. Cloning of non-human primates: The road "less traveled by". Int. J. Dev. Biol. 2010, 54, 1671-1678. [CrossRef]

100. Zhang, Y.; Li, J.; Villemoes, K.; Pedersen, A.M.; Purup, S.; Vajta, G. An epigenetic modifier results in improved in vitro blastocyst production after somatic cell nuclear transfer. Cloning Stem Cells 2007, 9, 357-363. [CrossRef]

101. Akagi, S.; Matsukawa, K.; Mizutani, E.; Fukunari, K.; Kaneda, M.; Watanabe, S.; Takahashi, S. Treatment with a histone deacetylase inhibitor after nuclear transfer improves the preimplantation development of cloned bovine embryos. J. Reprod. Dev. 2011, 57, 120-126. [CrossRef] [PubMed]

102. Srirattana, K.; Ketudat-Cairns, M.; Nagai, T.; Kaneda, M.; Parnpai, R. Effects of trichostatin A on in vitro development and DNA methylation level of the satellite I region of swamp buffalo (Bubalus bubalis) cloned embryos. J. Reprod. Dev. 2014, 60, 336-341. [CrossRef]

103. Liu, Z.; Cai, Y.; Wang, Y.; Nie, Y.; Zhang, C.; Xu, Y.; Zhang, X.; Lu, Y.; Wang, Z.; Poo, M.; et al. Cloning of macaque monkeys by somatic cell nuclear transfer. Cell 2018, 172, 881-887.e7. [CrossRef] [PubMed]

104. Van Thuan, N.; Bui, H.-T.T.; Kim, J.-H.H.; Hikichi, T.; Wakayama, S.; Kishigami, S.; Mizutani, E.; Wakayama, T. The histone deacetylase inhibitor scriptaid enhances nascent mRNA production and rescues full-term development in cloned inbred mice. Reproduction 2009, 138, 309-317. [CrossRef]

105. Tsuji, Y.; Kato, Y.; Tsunoda, Y. The developmental potential of mouse somatic cell nuclear-transferred oocytes treated with trichostatin A and 5-aza-2'-deoxycytidine. Zygote 2009, 17, 109-115. [CrossRef] [PubMed]

106. Guo, Z.; Lv, L.; Liu, D.; Fu, B. Effects of trichostatin A on pig SCNT blastocyst formation rate and cell number: A meta-analysis. Res. Vet. Sci. 2018, 117, 161-166. [CrossRef]

107. Samiec, M.; Romanek, J.; Lipiński, D.; Opiela, J. Expression of pluripotency-related genes is highly dependent on trichostatin Aassisted epigenomic modulation of porcine mesenchymal stem cells analysed for apoptosis and subsequently used for generating cloned embryos. Anim. Sci. J. 2019, 90, 1127-1141. [CrossRef]

108. Huan, Y.; Wang, H.; Wu, Z.; Zhang, J.; Zhu, J.; Liu, Z.; He, H. Epigenetic modification of cloned embryos improves Nanog reprogramming in pigs. Cell. Reprogram. 2015, 17, 191-198. [CrossRef] 
109. Cao, Z.; Hong, R.; Ding, B.; Zuo, X.; Li, H.; Ding, J.; Li, Y.; Huang, W.; Zhang, Y. TSA and BIX-01294 induced normal DNA and histone methylation and increased protein expression in porcine somatic cell nuclear transfer embryos. PLoS ONE 2017, 12, e0169092. [CrossRef]

110. Cui, X.-S.; Xu, Y.-N.; Shen, X.-H.; Zhang, L.-Q.; Zhang, J.-B.; Kim, N.-H. Trichostatin A modulates apoptotic-related gene expression and improves embryo viability in cloned bovine embryos. Cell. Reprogram. 2011, 13, 179-189. [CrossRef]

111. Oh, H.J.; Lee, T.H.; Lee, J.H.; Lee, B.C. Trichostatin A improves preimplantation development of bovine cloned embryos and alters expression of epigenetic and pluripotency genes in cloned blastocysts. J. Vet. Med. Sci. 2012, 74, 1409-1415. [CrossRef] [PubMed]

112. Sangalli, J.R.; De Bem, T.H.; Perecin, F.; Chiaratti, M.R.; Oliveira Lde, J.; de Araújo, R.R.; Valim Pimentel, J.R.; Smith, L.C.; Meirelles, F.V. Treatment of nuclear-donor cells or cloned zygotes with chromatin-modifying agents increases histone acetylation but does not improve full-term development of cloned cattle. Cell. Reprogram. 2012, 14, 235-247. [CrossRef]

113. Al-Ghadi, M.Q.; Alhimaidi, A.R.; Iwamoto, D.; Al-Mutary, M.G.; Ammari, A.A.; Saeki, K.O.; Aleissa, M.S. The in vitro development of cloned sheep embryos treated with Scriptaid and trichostatin (A). Saudi J. Biol. Sci. 2020, 27, 2280-2286. [CrossRef] [PubMed]

114. Srirattana, K.; Imsoonthornruksa, S.; Laowtammathron, C.; Sangmalee, A.; Tunwattana, W.; Thongprapai, T.; Chaimongkol, C.; Ketudat-Cairns, M.; Parnpai, R. Full-term development of gaur-bovine interspecies somatic cell nuclear transfer embryos: Effect of Trichostatin A treatment. Cell. Reprogram. 2012, 14, 248-257. [CrossRef] [PubMed]

115. Meng, Q.; Polgar, Z.; Liu, J.; Dinnyes, A. Live birth of somatic cell-cloned rabbits following trichostatin a treatment and cotransfer of parthenogenetic embryos. Cloning Stem Cells 2009, 11, 203-208. [CrossRef]

116. Matoba, S.; Liu, Y.; Lu, F.; Iwabuchi, K.A.; Shen, L.; Inoue, A.; Zhang, Y. Embryonic development following somatic cell nuclear transfer impeded by persisting histone methylation. Cell 2014, 159, 884-895. [CrossRef]

117. Yang, G.; Zhang, L.; Liu, W.; Qiao, Z.; Shen, S.; Zhu, Q.; Gao, R.; Wang, M.; Wang, M.; Li, C.; et al. Dux-mediated corrections of aberrant H3K9ac during 2-cell genome activation optimize efficiency of somatic cell nuclear transfer. Cell Stem Cell 2021, 28, 150-163.e5. [CrossRef]

118. Zhao, J.; Ross, J.W.; Hao, Y.; Spate, L.D.; Walters, E.M.; Samuel, M.S.; Rieke, A.; Murphy, C.N.; Prather, R.S. Significant improvement in cloning efficiency of an inbred miniature pig by histone deacetylase inhibitor treatment after somatic cell nuclear transfer. Biol. Reprod. 2009, 81, 525-530. [CrossRef]

119. Wen, B.Q.; Li, J.; Li, J.J.; Tian, S.J.; Sun, S.C.; Qi, X.; Cai, W.T.; Chang, Q.L. The histone deacetylase inhibitor Scriptaid improves in vitro developmental competence of ovine somatic cell nuclear transferred embryos. Theriogenology 2014, 81, 332-339. [CrossRef]

120. Li, W.; Xu, H.; Yin, Y.; Shen, W.; Sun, Q.Y.; Zhao, M. In vitro production of canine blastocysts. Theriogenology 2019, 135, 164-168. [CrossRef]

121. Ongaratto, F.L.; Rodriguez-Villamil, P.; Bertolini, M.; Carlson, D.F. Influence of oocyte selection, activation with a zinc chelator and inhibition of histone deacetylases on cloned porcine embryo and chemically activated oocytes development. Zygote 2020, 28, 286-290. [CrossRef] [PubMed]

122. Sun, J.; Liu, Q.; Lv, L.; Sun, R.; Li, Z.P.; Huang, B.; Cui, K.; Shi, D. HDAC6 is involved in the histone deacetylation of in vitro maturation oocytes and the reprogramming of nuclear transplantation in pig. Reprod. Sci. 2021, 28, 2630-2640. [CrossRef]

123. Das, Z.C.; Gupta, M.K.; Uhm, S.J.; Lee, H.T. Increasing histone acetylation of cloned embryos, but not donor cells, by sodium butyrate improves their in vitro development in pigs. Cell. Reprogram. 2010, 12, 95-104. [CrossRef] [PubMed]

124. Dai, X.; Hao, J.; Hou, X.-J.J.; Hai, T.; Fan, Y.; Yu, Y.; Jouneau, A.; Wang, L.; Zhou, Q. Somatic nucleus reprogramming is significantly improved by m-carboxycinnamic acid bishydroxamide, a histone deacetylase inhibitor. J. Biol. Chem. 2010, 285, 31002-31010. [CrossRef] [PubMed]

125. Ono, T.; Li, C.; Mizutani, E.; Terashita, Y.; Yamagata, K.; Wakayama, T. Inhibition of class Ilb histone deacetylase significantly improves cloning efficiency in mice. Biol. Reprod. 2010, 83, 929-937. [CrossRef]

126. Miyoshi, K.; Mori, H.; Mizobe, Y.; Akasaka, E.; Ozawa, A.; Yoshida, M.; Sato, M. Valproic acid enhances in vitro development and Oct-3/4 expression of miniature pig somatic cell nuclear transfer embryos. Cell. Reprogram. 2010, 12, 67-74. [CrossRef]

127. Mallol, A.; Santaló, J.; Ibáñez, E. Psammaplin A improves development and quality of somatic cell nuclear transfer mouse embryos. Cell. Reprogram. 2014, 16, 392-406. [CrossRef] [PubMed]

128. Jin, L.; Zhu, H.-Y.; Guo, Q.; Li, X.-C.; Zhang, Y.-C.; Zhang, G.-L.; Xing, X.-X.; Xuan, M.-F.; Luo, Q.-R.; Yin, X.-J.; et al. PCI-24781 can improve in vitro and in vivo developmental capacity of pig somatic cell nuclear transfer embryos. Biotechnol. Lett. 2016, 38, 1433-1441. [CrossRef]

129. Qiu, X.; You, H.; Xiao, X.; Li, N.; Li, Y. Effects of Trichostatin A and PXD101 on the in vitro development of mouse somatic cell nuclear transfer embryos. Cell. Reprogram. 2017, 19, 1-9. [CrossRef]

130. Jin, J.X.; Lee, S.; Taweechaipaisankul, A.; Kim, G.A.; Lee, B.C. The HDAC inhibitor LAQ824 enhances epigenetic reprogramming and in vitro development of porcine SCNT embryos. Cell. Physiol. Biochem. 2017, 41, 1255-1266. [CrossRef]

131. Jin, L.; Zhu, H.Y.; Guo, Q.; Li, X.C.; Zhang, Y.C.; Cui, C.D.; Li, W.X.; Cui, Z.Y.; Yin, X.J.; Kang, J.D. Effect of histone acetylation modification with MGCD0103, a histone deacetylase inhibitor, on nuclear reprogramming and the developmental competence of porcine somatic cell nuclear transfer embryos. Theriogenology 2017, 87, 298-305. [CrossRef] [PubMed]

132. Jin, L.; Guo, Q.; Zhu, H.Y.; Xing, X.X.; Zhang, G.L.; Xuan, M.F.; Luo, Q.R.; Luo, Z.B.; Wang, J.X.; Yin, X.J.; et al. Quisinostat treatment improves histone acetylation and developmental competence of porcine somatic cell nuclear transfer embryos. Mol. Reprod. Dev. 2017, 84, 340-346. [CrossRef] 
133. Enright, B.P.; Kubota, C.; Yang, X.; Tian, X.C. Epigenetic characteristics and development of embryos cloned from donor cells treated by trichostatin A or 5-aza-2'-deoxycytidine. Biol. Reprod. 2003, 69, 896-901. [CrossRef] [PubMed]

134. Jeon, B.G.; Coppola, G.; Perrault, S.D.; Rho, G.J.; Betts, D.H.; King, W.A. S-adenosylhomocysteine treatment of adult female fibroblasts alters $\mathrm{X}$-chromosome inactivation and improves in vitro embryo development after somatic cell nuclear transfer. Reproduction 2008, 135, 815-828. [CrossRef] [PubMed]

135. Shi, W.; Hoeflich, A.; Flaswinkel, H.; Stojkovic, M.; Wolf, E.; Zakhartchenko, V. Induction of a senescent-like phenotype does not confer the ability of bovine immortal cells to support the development of nuclear transfer embryos. Biol. Reprod. 2003, 69, 301-309. [CrossRef]

136. Ding, X.; Wang, Y.; Zhang, D.; Wang, Y.; Guo, Z.; Zhang, Y. Increased pre-implantation development of cloned bovine embryos treated with 5-aza-2'-deoxycytidine and trichostatin A. Theriogenology 2008, 70, 622-630. [CrossRef]

137. Saini, M.; Selokar, N.L.; Agrawal, H.; Singla, S.K.; Chauhan, M.S.; Manik, R.S.; Palta, P. Treatment of buffalo (Bubalus bubalis) donor cells with trichostatin A and 5-aza-2'-deoxycytidine alters their growth characteristics, gene expression and epigenetic status and improves the in vitro developmental competence, quality and epigenetic status of cloned embryos. Reprod. Fertil. Dev. 2016, 28, 824-837.

138. Yang, F.; Hao, R.; Kessler, B.; Brem, G.; Wolf, E.; Zakhartchenko, V. Rabbit somatic cell cloning: Effects of donor cell type, histone acetylation status and chimeric embryo complementation. Reproduction 2007, 133, 219-230. [CrossRef] [PubMed]

139. Fang, X.; Xia, W.; Cao, H.; Guo, Y.; Wang, H.; Zhang, X.; Wan, P.; Liu, C.; Wei, Q.; Sun, S.; et al. Effect of supplementation of Zebularine and Scriptaid on efficiency of in vitro developmental competence of ovine somatic cell nuclear transferred embryos. Anim. Biotechnol. 2020, 31, 155-163. [CrossRef] [PubMed]

140. Samiec, M.; Skrzyszowska, M. Intrinsic and extrinsic molecular determinants or modulators for epigenetic remodeling and reprogramming of somatic cell-derived genome in mammalian nuclear-transferred oocytes and resultant embryos. Pol. J. Vet. Sci. 2018, 21, 217-227. [PubMed]

141. Kamimura, S.; Inoue, K.; Mizutani, E.; Kim, J.M.; Inoue, H.; Ogonuki, N.; Miyamoto, K.; Ihashi, S.; Itami, N.; Wakayama, T.; et al. Improved development of mouse SCNT embryos by chlamydocin analogues, class I and IIa histone deacetylase inhibitors. Biol. Reprod. 2021, 105, 543-553. [CrossRef] [PubMed]

142. Rathbone, A.J.; Fisher, P.A.; Lee, J.H.; Craigon, J.; Campbell, K.H. Reprogramming of ovine somatic cells with Xenopus laevis oocyte extract prior to SCNT improves live birth rate. Cell. Reprogram. 2010, 12, 609-616. [CrossRef] [PubMed]

143. Bui, H.T.; Kwon, D.N.; Kang, M.H.; Oh, M.H.; Park, M.R.; Park, W.J.; Paik, S.S.; Van Thuan, N.; Kim, J.H. Epigenetic reprogramming in somatic cells induced by extract from germinal vesicle stage pig oocytes. Development 2012, 139, 4330-4340. [CrossRef] [PubMed]

144. Minor, E.A.; Court, B.L.; Young, J.I.; Wang, G. Ascorbate induces ten-eleven translocation (Tet) methylcytosine dioxygenasemediated generation of 5-hydroxymethylcytosine. J. Biol. Chem. 2013, 288, 13669-13674. [CrossRef]

145. Chen, H.; Zhang, L.; Guo, Z.; Wang, Y.; He, R.; Qin, Y.; Quan, F.; Zhang, Y. Improving the development of early bovine somatic-cell nuclear transfer embryos by treating adult donor cells with vitamin C. Mol. Reprod. Dev. 2015, 82, 867-879. [CrossRef]

146. Huang, Y.; Tang, X.; Xie, W.; Zhou, Y.; Li, D.; Zhou, Y.; Zhu, J.; Yuan, T.; Lai, L.; Pang, D.; et al. Vitamin C enhances in vitro and in vivo development of porcine somatic cell nuclear transfer embryos. Biochem. Biophys. Res. Commun. 2011, 411, 397-401. [CrossRef]

147. Chawalit, S.; Nguyen, N.T.; Tseng, J.K.; Lo, N.W.; Tu, C.F.; Ju, J.C. Trichostatin A and ascorbic acid assist in the development of porcine handmade cloned embryos via different physiologic pathways. Reprod. Sci. 2012, 19, 976-986. [CrossRef]

148. Mallol, A.; Santaló, J.; Ibáñez, E. Improved development of somatic cell cloned mouse embryos by vitamin C and latrunculin A. PLoS ONE 2015, 10, e0120033. [CrossRef]

149. Zhang, Y.; Gao, E.; Guan, H.; Wang, Q.; Zhang, S.; Liu, K.; Yan, F.; Tian, H.; Shan, D.; Xu, H.; et al. Vitamin C treatment of embryos, but not donor cells, improves the cloned embryonic development in sheep. Reprod. Domest. Anim. 2020, 55, 255-265. [CrossRef]

150. Miyamoto, K.; Tajima, Y.; Yoshida, K.; Oikawa, M.; Azuma, R.; Allen, G.E.; Tsujikawa, T.; Tsukaguchi, T.; Bradshaw, C.R.; Jullien, J.; et al. Reprogramming towards totipotency is greatly facilitated by synergistic effects of small molecules. Biol. Open. 2017, 6, 415-424. [CrossRef]

151. An, Q.; Peng, W.; Cheng, Y.; Lu, Z.; Zhou, C.; Zhang, Y.; Su, J. Melatonin supplementation during in vitro maturation of oocyte enhances subsequent development of bovine cloned embryos. J. Cell. Physiol. 2019, 234, 17370-17381. [CrossRef]

152. Qu, P.; Zuo, Z.; Liu, Z.; Niu, Z.; Zhang, Y.; Du, Y.; Ma, X.; Qiao, F.; Wang, M.; Zhang, Y.; et al. Sperm-borne small RNAs regulate $\alpha$-tubulin acetylation and epigenetic modification of early bovine somatic cell nuclear transfer embryos. Mol. Hum. Reprod. 2019, 25, 471-482. [CrossRef] [PubMed]

153. Qin, H.; Qu, P.; Hu, H.; Cao, W.; Liu, H.; Zhang, Y.; Zhao, J.; Nazira, F.; Liu, E. Sperm-borne small RNAs improve the developmental competence of pre-implantation cloned embryos in rabbit. Zygote 2021, 29, 331-336. [CrossRef] [PubMed]

154. Jambhekar, A.; Dhall, A.; Shi, Y. Roles and regulation of histone methylation in animal development. Nat. Rev. Mol. Cell Biol. 2019, 20, 625-641. [CrossRef]

155. Liu, W.; Liu, X.; Wang, C.; Gao, Y.; Gao, R.; Kou, X.; Zhao, Y.; Li, J.; Wu, Y.; Xiu, W.; et al. Identification of key factors conquering developmental arrest of somatic cell cloned embryos by combining embryo biopsy and single-cell sequencing. Cell Discov. 2016, 2, 16010. [CrossRef] 
156. Santos, F.; Zakhartchenko, V.; Stojkovic, M.; Peters, A.; Jenuwein, T.; Wolf, E.; Reik, W.; Dean, W. Epigenetic marking correlates with developmental potential in cloned bovine preimplantation embryos. Curr. Biol. 2003, 13, 1116-1121. [CrossRef]

157. Pichugin, A.; Le Bourhis, D.; Adenot, P.; Lehmann, G.; Audouard, C.; Renard, J.P.; Vignon, X.; Beaujean, N. Dynamics of constitutive heterochromatin: Two contrasted kinetics of genome restructuring in early cloned bovine embryos. Reproduction 2010, 139, 129-137. [CrossRef]

158. Ribeiro-Mason, K.; Boulesteix, C.; Fleurot, R.; Aguirre-Lavin, T.; Adenot, P.; Gall, L.; Debey, P.; Beaujean, N. H3S10 phosphorylation marks constitutive heterochromatin during interphase in early mouse embryos until the 4-cell stage. J. Reprod. Dev. 2012, 58, 467-475. [CrossRef] [PubMed]

159. Yang, C.X.; Liu, Z.; Fleurot, R.; Adenot, P.; Duranthon, V.; Vignon, X.; Zhou, Q.; Renard, J.P.; Beaujean, N. Heterochromatin reprogramming in rabbit embryos after fertilization, intra-, and inter-species SCNT correlates with preimplantation development. Reproduction 2013, 145, 149-159. [CrossRef] [PubMed]

160. Chung, Y.G.; Matoba, S.; Liu, Y.; Eum, J.H.; Lu, F.; Jiang, W.; Lee, J.E.; Sepilian, V.; Cha, K.Y.; Lee, D.R.; et al. Histone demethylase expression enhances human somatic cell nuclear transfer efficiency and promotes derivation of pluripotent stem cells. Cell Stem Cell 2015, 17, 758-766. [CrossRef] [PubMed]

161. Zhang, Y.; Wang, Q.; Liu, K.; Gao, E.; Guan, H.; Hou, J. Treatment of donor cells with recombinant KDM4D protein improves preimplantation development of cloned ovine embryos. Cytotechnology 2018, 70, 1469-1477. [CrossRef]

162. Liu, X.; Wang, Y.; Gao, Y.; Su, J.; Zhang, J.; Xing, X.; Zhou, C.; Yao, K.; An, Q.; Zhang, Y. H3K9 demethylase KDM4E is an epigenetic regulator for bovine embryonic development and a defective factor for nuclear reprogramming. Development 2018, 145, dev158261. [CrossRef] [PubMed]

163. Zhang, J.; Hao, L.; Wei, Q.; Zhang, S.; Cheng, H.; Zhai, Y.; Jiang, Y.; An, X.; Li, Z.; Zhang, X.; et al. TET3 overexpression facilitates DNA reprogramming and early development of bovine SCNT embryos. Reproduction 2020, 160, 379-391. [CrossRef] [PubMed]

164. Ruan, D.; Peng, J.; Wang, X.; Ouyang, Z.; Zou, Q.; Yang, Y.; Chen, F.; Ge, W.; Wu, H.; Liu, Z.; et al. XIST derepression in active X chromosome hinders pig somatic cell nuclear transfer. Stem Cell Rep. 2018, 10, 494-508. [CrossRef]

165. Meng, F.; Stamms, K.; Bennewitz, R.; Green, A.; Oback, F.; Turner, P.; Wei, J.; Oback, B. Targeted histone demethylation improves somatic cell reprogramming into cloned blastocysts but not postimplantation bovine concepti. Biol. Reprod. 2020, 103, 114-125. [CrossRef] [PubMed]

166. Zhou, C.; Zhang, J.; Zhang, M.; Wang, D.; Ma, Y.; Wang, Y.; Wang, Y.; Huang, Y.; Zhang, Y. Transcriptional memory inherited from donor cells is a developmental defect of bovine cloned embryos. FASEB J. 2020, 34, 1637-1651. [CrossRef] [PubMed]

167. Huang, J.; Zhang, H.; Yao, J.; Qin, G.; Wang, F.; Wang, X.; Luo, A.; Zheng, Q.; Cao, C.; Zhao, J. BIX-01294 increases pig cloning efficiency by improving epigenetic reprogramming of somatic cell nuclei. Reproduction 2016, 151, 39-49. [CrossRef]

168. Huang, Y.; Jiang, X.; Yu, M.; Huang, R.; Yao, J.; Li, M.; Zheng, F.; Yang, X. Beneficial effects of diazepin-quinazolin-amine derivative (BIX-01294) on preimplantation development and molecular characteristics of cloned mouse embryos. Reprod. Fertil. Dev. 2017, 29, 1260-1269. [CrossRef]

169. Weng, X.G.; Cai, M.M.; Zhang, Y.T.; Liu, Y.; Liu, C.; Liu, Z.H. Improvement in the in vitro development of cloned pig embryos after KDM4A overexpression and an H3K9me3 methyltransferase inhibitor treatment. Theriogenology 2020, 146, 162-170. [CrossRef]

170. Jeong, P.S.; Sim, B.W.; Park, S.H.; Kim, M.J.; Kang, H.G.; Nanjidsuren, T.; Lee, S.; Song, B.S.; Koo, D.B.; Kim, S.U. Chaetocin improves pig cloning efficiency by enhancing epigenetic reprogramming and autophagic activity. Int. J. Mol. Sci. 2020, 21, 4836. [CrossRef]

171. Yang, L.; Song, L.; Liu, X.; Bai, L.; Li, G. KDM6A and KDM6B play contrasting roles in nuclear transfer embryos revealed by MERVL reporter system. EMBO Rep. 2018, 19, e46240. [CrossRef]

172. Xie, B.; Zhang, H.; Wei, R.; Li, Q.; Weng, X.; Kong, Q.; Liu, Z. Histone H3 lysine 27 trimethylation acts as an epigenetic barrier in porcine nuclear reprogramming. Reproduction 2016, 151, 9-16. [CrossRef] [PubMed]

173. Wang, L.Y.; Li, Z.K.; Wang, L.B.; Liu, C.; Sun, X.H.; Feng, G.H.; Wang, J.Q.; Li, Y.F.; Qiao, L.Y.; Nie, H.; et al. Overcoming intrinsic H3K27me3 imprinting barriers improves post-implantation development after somatic cell nuclear transfer. Cell Stem Cell 2020, 27, 315-325.e5. [CrossRef]

174. Jafarpour, F.; Ghazvini Zadegan, F.; Ostadhosseini, S.; Hajian, M.; Kiani-Esfahani, A.; Nasr-Esfahani, M.H. siRNA inhibition and not chemical inhibition of Suv39h1/2 enhances pre-implantation embryonic development of bovine somatic cell nuclear transfer embryos. PLoS ONE 2020, 15, e0233880. [CrossRef] [PubMed]

175. Bourc'his, D.; Le Bourhis, D.; Patin, D.; Niveleau, A.; Comizzoli, P.; Renard, J.; Viegas-Péquignot, E. Delayed and incomplete reprogramming of chromosome methylation patterns in bovine cloned embryos. Curr. Biol. 2001, 11, 1542-1546. [CrossRef]

176. Jones, K.L.; Hill, J.; Shin, T.Y.; Lui, L.; Westhusin, M. DNA hypomethylation of karyoplasts for bovine nuclear transplantation. Mol. Reprod. Dev. 2001, 60, 208-213. [CrossRef] [PubMed]

177. Mohana Kumar, B.; Jin, H.F.; Kim, J.G.; Song, H.J.; Hong, Y.; Balasubramanian, S.; Choe, S.Y.; Rho, G.J. DNA methylation levels in porcine fetal fibroblasts induced by an inhibitor of methylation, 5-azacytidine. Cell Tissue Res. 2006, 325, 445-454. [CrossRef]

178. Xu, W.; Li, Z.; Yu, B.; He, X.; Shi, J.; Zhou, R.; Liu, D.; Wu, Z. Effects of DNMT1 and HDAC inhibitors on gene-specific methylation reprogramming during porcine somatic cell nuclear transfer. PLoS ONE 2013, 8, e64705. [CrossRef]

179. Adams, A.M.; Pratt, S.L.; Stice, S.L. Knockdown of the Dnmt1s transcript using small interfering RNA in primary murine and bovine fibroblast cells. Mol. Reprod. Dev. 2005, 72, 311-319. [CrossRef] 
180. Gao, R.; Wang, C.; Gao, Y.; Xiu, W.; Chen, J.; Kou, X.; Zhao, Y.; Liao, Y.; Bai, D.; Qiao, Z.; et al. Inhibition of aberrant DNA re-methylation improves post-implantation development of somatic cell nuclear transfer embryos. Cell Stem Cell 2018, 23, 426-435.e5. [CrossRef]

181. Meister, G.; Tuschl, T. Mechanisms of gene silencing by double-stranded RNA. Nature 2004, 431, 343-349. [CrossRef] [PubMed]

182. Wang, P.; Li, X.; Cao, L.; Huang, S.; Li, H.; Zhang, Y.; Yang, T.; Jiang, J.; Shi, D. MicroRNA-148a overexpression improves the early development of porcine somatic cell nuclear transfer embryos. PLoS ONE 2017, 12, e0180535. [CrossRef] [PubMed]

183. Wang, Z.D.; Duan, L.; Zhang, Z.H.; Song, S.H.; Bai, G.Y.; Zhang, N.; Shen, X.H.; Shen, J.L.; Lei, L. Methyl-CpG-binding protein 2 improves the development of mouse somatic cell nuclear transfer embryos. Cell. Reprogram. 2016, 18, 78-86. [CrossRef] [PubMed]

184. Han, C.; Deng, R.; Mao, T.; Luo, Y.; Wei, B.; Meng, P.; Zhao, L.; Zhang, Q.; Quan, F.; Liu, J.; et al. Overexpression of Tet3 in donor cells enhances goat somatic cell nuclear transfer efficiency. FEBS J. 2018, 285, 2708-2723. [CrossRef]

185. Wang, X.; Shi, J.; Cai, G.; Zheng, E.; Liu, D.; Wu, Z.; Li, Z. Overexpression of MBD3 improves reprogramming of cloned pig embryos. Cell. Reprogram. 2019, 21, 221-228. [CrossRef] [PubMed]

186. MacGregor, I.A.; Adams, I.R.; Gilbert, N. Large-scale chromatin organisation in interphase, mitosis and meiosis. Biochem. J. 2019, 476, 2141-2156. [CrossRef]

187. Zheng, H.; Xie, W. The role of 3D genome organization in development and cell differentiation. Nat. Rev. Mol. Cell Biol. 2019, 20, 535-550. [CrossRef]

188. Lieberman-Aiden, E.; van Berkum, N.L.; Williams, L.; Imakaev, M.; Ragoczy, T.; Telling, A.; Amit, I.; Lajoie, B.R.; Sabo, P.J.; Dorschner, M.O.; et al. Comprehensive mapping of long-range interactions reveals folding principles of the human genome. Science 2009, 326, 289-293. [CrossRef]

189. Chen, M.; Zhu, Q.; Li, C.; Kou, X.; Zhao, Y.; Li, Y.; Xu, R.; Yang, L.; Yang, L.; Gu, L.; et al. Chromatin architecture reorganization in murine somatic cell nuclear transfer embryos. Nat. Commun. 2020, 11, 1813. [CrossRef]

190. Haarhuis, J.H.I.; van der Weide, R.H.; Blomen, V.A.; Yáñez-Cuna, J.O.; Amendola, M.; van Ruiten, M.S.; Krijger, P.H.L.; Teunissen, H.; Medema, R.H.; van Steensel, B.; et al. The cohesin release factor WAPL restricts chromatin loop extension. Cell 2017, 169, 693-707.e14. [CrossRef]

191. Rao, S.S.P.; Huang, S.C.; Glenn St Hilaire, B.; Engreitz, J.M.; Perez, E.M.; Kieffer-Kwon, K.R.; Sanborn, A.L.; Johnstone, S.E.; Bascom, G.D.; Bochkov, I.D.; et al. Cohesin loss eliminates all loop domains. Cell 2017, 171, 305-320.e24. [CrossRef]

192. Schwarzer, W.; Abdennur, N.; Goloborodko, A.; Pekowska, A.; Fudenberg, G.; Loe-Mie, Y.; Fonseca, N.A.; Huber, W.; Haering, C.H.; Mirny, L.; et al. Two independent modes of chromatin organization revealed by cohesin removal. Nature 2017, 551, 51-56. [CrossRef] [PubMed]

193. Zhang, K.; Wu, D.Y.; Zheng, H.; Wang, Y.; Sun, Q.R.; Liu, X.; Wang, L.Y.; Xiong, W.J.; Wang, Q.; Rhodes, J.D.P.; et al. Analysis of genome architecture during SCNT reveals a role of cohesin in impeding minor ZGA. Mol. Cell 2020, 79, 234-250.e9. [CrossRef]

194. Wang, Y.; Liu, Q.; Kang, J.; Zhang, Y.; Quan, F. Overexpression of PGC7 in donor cells maintains the DNA methylation status of imprinted genes in goat embryos derived from somatic cell nuclear transfer technology. Theriogenology 2020, 151, 86-94. [CrossRef] [PubMed]

195. Inoue, K.; Ogonuki, N.; Kamimura, S.; Inoue, H.; Matoba, S.; Hirose, M.; Honda, A.; Miura, K.; Hada, M.; Hasegawa, A.; et al. Loss of H3K27me3 imprinting in the Sfmbt2 miRNA cluster causes enlargement of cloned mouse placentas. Nat. Commun. 2020, 11, 2150. [CrossRef] [PubMed]

196. Matoba, S.; Wang, H.; Jiang, L.; Lu, F.; Iwabuchi, K.A.; Wu, X.; Inoue, K.; Yang, L.; Press, W.; Lee, J.T.; et al. Loss of H3K27me3 imprinting in somatic cell nuclear transfer embryos disrupts post-implantation development. Cell Stem Cell 2018, 23, 343-354.e5. [CrossRef] [PubMed]

197. Yu, D.; Wang, J.; Zou, H.; Feng, T.; Chen, L.; Li, J.; Qi, X.; Li, Z.; Duan, X.; Xu, C.; et al. Silencing of retrotransposon-derived imprinted gene RTL1 is the main cause for postimplantational failures in mammalian cloning. Proc. Natl. Acad. Sci. USA 2018, 115, E11071-E11080. [CrossRef]

198. Wang, Q.; Chow, J.; Hong, J.; Smith, A.F.; Moreno, C.; Seaby, P.; Vrana, P.; Miri, K.; Tak, J.; Chung, E.D.; et al. Recent acquisition of imprinting at the rodent Sfmbt2 locus correlates with insertion of a large block of miRNAs. BMC Genom. 2011, 12, 204. [CrossRef]

199. Brockdorff, N. The role of Xist in X-inactivation. Curr. Opin. Genet. Dev. 1998, 8, 328-333. [CrossRef]

200. Inoue, K.; Kohda, T.; Sugimoto, M.; Sado, T.; Ogonuki, N.; Matoba, S.; Shiura, H.; Ikeda, R.; Mochida, K.; Fujii, T.; et al. Impeding Xist expression from the active $X$ chromosome improves mouse somatic cell nuclear transfer. Science 2010, 330, 496-499. [CrossRef]

201. Wee, G.; Koo, D.B.; Song, B.S.; Kim, J.S.; Kang, M.J.; Moon, S.J.; Kang, Y.K.; Lee, K.K.; Han, Y.M. Inheritable histone H4 acetylation of somatic chromatins in cloned embryos. J. Biol. Chem. 2006, 281, 6048-6057. [CrossRef]

202. Yang, L.; Chavatte-Palmer, P.; Kubota, C.; O’Neill, M.; Hoagland, T.; Renard, J.P.; Taneja, M.; Yang, X.; Tian, X.C. Expression of imprinted genes is aberrant in deceased newborn cloned calves and relatively normal in surviving adult clones. Mol. Reprod. Dev. 2005, 71, 431-438. [CrossRef] [PubMed]

203. Matoba, S.; Inoue, K.; Kohda, T.; Sugimoto, M.; Mizutani, E.; Ogonuki, N.; Nakamura, T.; Abe, K.; Nakano, T.; Ishino, F.; et al. RNAi-mediated knockdown of Xist can rescue the impaired postimplantation development of cloned mouse embryos. Proc. Natl. Acad. Sci. USA 2011, 108, 20621-20626. [CrossRef] [PubMed]

204. Oikawa, M.; Matoba, S.; Inoue, K.; Kamimura, S.; Hirose, M.; Ogonuki, N.; Shiura, H.; Sugimoto, M.; Abe, K.; Ishino, F.; et al. RNAi-mediated knockdown of Xist does not rescue the impaired development of female cloned mouse embryos. J. Reprod. Dev. 2013, 59, 231-237. [CrossRef] 
205. Zeng, F.; Huang, Z.; Yuan, Y.; Shi, J.; Cai, G.; Liu, D.; Wu, Z.; Li, Z. Effects of RNAi-mediated knockdown of Xist on the developmental efficiency of cloned male porcine embryos. J. Reprod. Dev. 2016, 62, 591-597. [CrossRef] [PubMed]

206. Yang, X.; Wu, X.; Yang, Y.; Gu, T.; Hong, L.; Zheng, E.; Xu, Z.; Zeng, F.; Shi, J.; Zhou, R.; et al. Improvement of developmental competence of cloned male pig embryos by short hairpin ribonucleic acid (shRNA) vector-based but not small interfering RNA (siRNA)-mediated RNA interference (RNAi) of Xist expression. J. Reprod. Dev. 2019, 65, 533-539. [CrossRef] [PubMed]

207. Lédée, N.; Frydman, R.; Osipova, A.; Taieb, J.; Gallot, V.; Lombardelli, L.; Logiodice, F.; Petitbarat, M.; Fanchin, R.; Chaouat, G.; et al. Levels of follicular G-CSF and interleukin-15 appear as noninvasive biomarkers of subsequent successful birth in modified natural in vitro fertilization/intracytoplasmic sperm injection cycles. Fertil. Steril. 2011, 95, 94-98. [CrossRef]

208. Cai, L.; Jeong, Y.W.; Jin, Y.X.; Lee, J.Y.; Jeong, Y.I.; Hwang, K.C.; Hyun, S.H.; Hwang, W.S. Effects of human recombinant granulocyte-colony stimulating factor treatment during in vitro culture on porcine pre-implantation embryos. PLoS ONE 2020, 15, e0230247. [CrossRef]

209. Ashry, M.; Yang, C.; Rajput, S.K.; Folger, J.K.; Knott, J.G.; Smith, G.W. Follistatin supplementation induces changes in CDX2 CpG methylation and improves in vitro development of bovine SCNT preimplantation embryos. Reprod. Biol. Endocrinol. 2021, 19, 141. [CrossRef]

210. Ridlo, M.R.; Kim, E.H.; Taweechaipaisankul, A.; Lee, B.C.; Kim, G.A. Adiponectin improves in vitro development of cloned porcine embryos by reducing endoplasmic reticulum stress and apoptosis. Animals 2021, 11, 473. [CrossRef]

211. Wang, X.; Zhu, X.; Liang, X.; Xu, H.; Liao, Y.; Lu, K.; Lu, S. Effects of resveratrol on in vitro maturation of porcine oocytes and subsequent early embryonic development following somatic cell nuclear transfer. Reprod. Domest. Anim. 2019, 54, 1195-1205. [CrossRef] [PubMed]

212. Wu, C.; Zhang, D.; Zhang, S.; Sun, L.; Liu, Y.; Dai, J. Effect of Rhodiola sachalinensis aqueous extract on in vitro maturation of porcine oocytes and subsequent in vitro embryonic development. Cell. Reprogram. 2020, 22, 277-281. [CrossRef]

213. Qi, J.J.; Li, X.X.; Diao, Y.F.; Liu, P.L.; Wang, D.L.; Bai, C.Y.; Yuan, B.; Liang, S.; Sun, B.X. Asiatic acid supplementation during the in vitro culture period improves early embryonic development of porcine embryos produced by parthenogenetic activation, somatic cell nuclear transfer and in vitro fertilization. Theriogenology 2020, 142, 26-33. [CrossRef]

214. Roy, P.K.; Qamar, A.Y.; Tanga, B.M.; Bang, S.; Seong, G.; Fang, X.; Kim, G.; Edirisinghe, S.L.; De Zoysa, M.; Kang, D.H.; et al. Modified Spirulina maxima pectin nanoparticles improve the developmental competence of in vitro matured porcine oocytes. Animals 2021, 11, 2483. [CrossRef] [PubMed]

215. Do, L.T.; Luu, V.V.; Morita, Y.; Taniguchi, M.; Nii, M.; Peter, A.T.; Otoi, T. Astaxanthin present in the maturation medium reduces negative effects of heat shock on the developmental competence of porcine oocytes. Reprod. Biol. 2015, 15, 86-93. [CrossRef] [PubMed]

216. Kuroki, T.; Ikeda, S.; Okada, T.; Maoka, T.; Kitamura, A.; Sugimoto, M.; Kume, S. Astaxanthin ameliorates heat stress-induced impairment of blastocyst development in vitro: Astaxanthin colocalization with and action on mitochondria. J. Assist. Reprod. Genet. 2013, 30, 623-631. [CrossRef]

217. Xiang, D.C.; Jia, B.Y.; Fu, X.W.; Guo, J.X.; Hong, Q.H.; Quan, G.B.; Wu, G.Q. Role of astaxanthin as an efficient antioxidant on the in vitro maturation and vitrification of porcine oocytes. Theriogenology 2021, 167, 13-23. [CrossRef] [PubMed]

218. Chen, S.; Zhang, Q.; Wu, X.; Schultz, P.G.; Ding, S. Dedifferentiation of lineage-committed cells by a small molecule. J. Am. Chem. Soc. 2004, 126, 410-411. [CrossRef]

219. Chen, S.; Takanashi, S.; Zhang, Q.; Xiong, W.; Zhu, S.; Peters, E.C.; Ding, S.; Schultz, P.G. Reversine increases the plasticity of lineage-committed mammalian cells. Proc. Natl. Acad. Sci. USA 2007, 104, 10482-10487. [CrossRef]

220. Kim, Y.K.; Choi, H.Y.; Kim, N.H.; Lee, W.; Seo, D.W.; Kang, D.W.; Lee, H.Y.; Han, J.W.; Park, S.W.; Kim, S.N. Reversine stimulates adipocyte differentiation and downregulates Akt and p70(s6k) signaling pathways in 3T3-L1 cells. Biochem. Biophys. Res. Commun. 2007, 358, 553-558. [CrossRef]

221. Saraiya, M.; Nasser, R.; Zeng, Y.; Addya, S.; Ponnappan, R.K.; Fortina, P.; Anderson, D.G.; Albert, T.J.; Shapiro, I.M.; Risbud, M.V. Reversine enhances generation of progenitor-like cells by dedifferentiation of annulus fibrosus cells. Tissue Eng. Part A 2010, 16, 1443-1455. [CrossRef]

222. Miyoshi, K.; Mori, H.; Mizobe, Y.; Himaki, T.; Yoshida, M.; Sato, M. Beneficial effects of Reversine on in vitro development of miniature pig somatic cell nuclear transfer embryos. J. Reprod. Dev. 2010, 56, 291-296. [CrossRef]

223. Li, J.; Foote, R.H. Differential sensitivity of one-cell and two-cell rabbit embryos to sodium chloride and total osmolarity during culture into blastocysts. J. Reprod. Fertil. 1996, 108, 307-312. [CrossRef]

224. Collins, J.L.; Baltz, J.M. Estimates of mouse oviductal fluid tonicity based on osmotic responses of embryos. Biol. Reprod. 1999, 60, 1188-1193. [CrossRef] [PubMed]

225. Lee, Y.; Lee, H.; Lee, J.; Lee, S.T.; Lee, G.S.; Lee, E. Glucose in a maturation medium with reduced NaCl improves oocyte maturation and embryonic development after somatic cell nuclear transfer and in vitro fertilization in pigs. Zygote 2021, 29, 293-300. [CrossRef] [PubMed]

226. Sharma, A.K.; Sah, S.; Singla, S.K.; Chauhan, M.S.; Manik, R.S.; Palta, P. Exposure to pulsed electromagnetic fields improves the developmental competence and quality of somatic cell nuclear transfer buffalo (Bubalus bubalis) embryos produced using fibroblast cells and alters their epigenetic status and gene expression. Cell. Reprogram. 2021, 23, 304-315. [CrossRef] [PubMed] 
227. Jozi, M.; Jafarpour, F.; Moradi, R.; Zadegan, F.G.; Karbalaie, K.; Nasr-Esfahani, M.H. Induced DNA hypomethylation by folic acid deprivation in bovine fibroblast donor cells improves reprogramming of somatic cell nuclear transfer embryos. Sci. Rep. 2020, 10, 5076. [CrossRef]

228. Lee, Y.; Shim, J.; Ko, N.; Kim, H.J.; Park, J.K.; Kwak, K.; Kim, H.; Choi, K. Effect of alanine supplementation during in vitro maturation on oocyte maturation and embryonic development after parthenogenesis and somatic cell nuclear transfer in pigs. Theriogenology 2019, 127, 80-87. [CrossRef]

229. Kikuchi, K.; Naito, K.; Noguchi, J.; Shimada, A.; Kaneko, H.; Yamashita, M.; Aoki, F.; Tojo, H.; Toyoda, Y. Maturation/M-phase promoting factor: A regulator of aging in porcine oocytes. Biol. Reprod. 2000, 63, 715-722. [CrossRef]

230. Lee, J.H.; Campbell, K.H. Caffeine treatment prevents age-related changes in ovine oocytes and increases cell numbers in blastocysts produced by somatic cell nuclear transfer. Cloning Stem Cells 2008, 10, 381-390. [CrossRef]

231. Kim, G.; Roy, P.K.; Fang, X.; Hassan, B.M.; Cho, J. Improved preimplantation development of porcine somatic cell nuclear transfer embryos by caffeine treatment. J. Vet. Sci. 2019, 20, e31. [CrossRef]

232. Qasim, M.; Jin, J.X.; Lee, S.; Taweechaipaisankul, A.; Setyawan, E.M.N.; Kim, G.A.; Lee, B.C. Effects of manganese on maturation of porcine oocytes in vitro and their subsequent embryo development after parthenogenetic activation and somatic cell nuclear transfer. J. Reprod. Dev. 2019, 65, 259-265. [CrossRef]

233. Tepekoy, F.; Akkoyunlu, G.; Demir, R. The role of Wnt signaling members in the uterus and embryo during pre-implantation and implantation. J. Assist. Reprod. Genet. 2015, 32, 337-346. [CrossRef]

234. Shyam, S.; Goel, P.; Kumar, D.; Malpotra, S.; Singh, M.K.; Lathwal, S.S.; Chand, S.; Palta, P. Effect of Dickkopf-1 and colony stimulating factor-2 on the developmental competence, quality, gene expression and live birth rate of buffalo (Bubalus bubalis) embryos produced by hand-made cloning. Theriogenology 2020, 157, 254-262. [CrossRef]

235. Chia, G.; Agudo, J.; Treff, N.; Sauer, M.V.; Billing, D.; Brown, B.D.; Baer, R.; Egli, D. Genomic instability during reprogramming by nuclear transfer is DNA replication dependent. Nat. Cell Biol. 2017, 19, 282-291. [CrossRef]

236. Bhat, K.P.; Cortez, D. RPA and RAD51: Fork reversal, fork protection, and genome stability. Nat. Struct. Mol. Biol. 2018, 25, 446-453. [CrossRef] [PubMed]

237. Lee, A.R.; Park, J.H.; Shim, S.H.; Hong, K.; La, H.; Park, K.S.; Lee, D.R. Genome stabilization by RAD51-stimulatory compound 1 enhances efficiency of somatic cell nuclear transfer-mediated reprogramming and full-term development of cloned mouse embryos. Cell Prolif. 2021, 54, e13059. [CrossRef] [PubMed]

238. De Iaco, A.; Planet, E.; Coluccio, A.; Verp, S.; Duc, J.; Trono, D. DUX-family transcription factors regulate zygotic genome activation in placental mammals. Nat. Genet. 2017, 49, 941-945. [CrossRef] [PubMed]

239. Hendrickson, P.G.; Doráis, J.A.; Grow, E.J.; Whiddon, J.L.; Lim, J.W.; Wike, C.L.; Weaver, B.D.; Pflueger, C.; Emery, B.R.; Wilcox, A.L.; et al. Conserved roles of mouse DUX and human DUX4 in activating cleavage-stage genes and MERVL/HERVL retrotransposons. Nat. Genet. 2017, 49, 925-934. [CrossRef] [PubMed]

240. Whiddon, J.L.; Langford, A.T.; Wong, C.J.; Zhong, J.W.; Tapscott, S.J. Conservation and innovation in the DUX4-family gene network. Nat. Genet. 2017, 49, 935-940. [CrossRef] [PubMed]

241. Yang, L.; Liu, X.; Song, L.; Di, A.; Su, G.; Bai, C.; Wei, Z.; Li, G. Transient Dux expression facilitates nuclear transfer and induced pluripotent stem cell reprogramming. EMBO Rep. 2020, 21, e50054. [CrossRef] [PubMed]

242. Huang, X.; Hu, X.; Jiang, Q.; Cao, Q.; Wu, Y.; Lei, L. Functional study of distinct domains of Dux in improving mouse SCNT embryonic development. Biol. Reprod. 2021, 105, 1089-1103. [CrossRef] [PubMed] 